\title{
Ranavirus Ecology and Evolution: From Epidemiology to Extinction
}

\author{
Jesse L. Brunner, Andrew Storfer, Matthew J. Gray, \\ and Jason T. Hoverman
}

\section{Introduction}

Ranaviruses were thought to have little impact on populations of fish and amphibians for decades after their serendipitous discovery in primary kidney cell cultures of northern leopard frogs (Lithobates [formerly Rana] pipiens; Granoff et al. 1966; Chinchar et al. 2009; Williams et al. 2005). This view changed with increasing evidence that ranaviruses were responsible for widespread epidemics and mortality in several fishes and later amphibians (Ahne et al. 1997; Chinchar 2002; Williams et al. 2005). The growing interest in this genus of viruses is fueled by the apparent increases in geographic range, as well as evidence of population declines coming from a wide range of ectothermic vertebrates around the world (Duffus et al. 2015). Ranavirus die-offs in the wild and in captive settings are often marked by a rapid onset and high mortality, but less obvious ranaviral infections in natural populations can occur. Overall, ranavirus epidemics can result in a range of effects on population dynamics, from apparently benign infections to local extirpation. In this chapter, we will review the current status of ranavirus epidemiology, with a particular focus on

\footnotetext{
J.L. Brunner $(\square) \bullet A$. Storfer

School of Biological Sciences, Washington State University,

Pullman, WA 99164, USA

e-mail: jesse.brunner@wsu.edu; astorfer@wsu.edu

M.J. Gray

Center for Wildlife Health, Department of Forestry, Wildlife and Fisheries,

University of Tennessee, 274 Ellington Plant Sciences Building,

Knoxville, TN 37996, USA

e-mail: mgray11@utk.edu

J.T. Hoverman

Department of Forestry and Natural Resources, Purdue University,

West Lafayette, IN 47907, USA

e-mail: jhoverm@purdue.edu 
factors that can influence the outcome of ranavirus infections for individuals and populations. We will then discuss ranavirus transmission within and between species, and its consequences for ranavirus epidemiology. We also consider the evolution of ranaviruses with a focus on local adaptation and virulence, which is important to understand in light of the growing evidence that ranaviruses are being moved around the world by human activities. We end by returning to the impacts of ranaviruses on their hosts, considering whether ranaviruses can cause host extinctions.

\section{Epidemiology of Ranaviruses}

Most of what is known about the epidemiology, geography, and host range of ranaviruses comes from investigations of obvious die-offs, sporadic surveillance efforts in small numbers of populations and time points, and a few larger-scale surveillance efforts focused on a handful of species of economic importance or conservation interest (Grizzle and Brunner 2003; Gray et al. 2009a; Whittington et al. 2010; Miller et al. 2011; Duffus et al. 2015). Duffus et al. (2015) reviewed the known distribution and host range of ranaviruses. In total, six species of Ranavirus are recognized, causing infection or overt disease in at least 175 species (52 families) of ectothermic vertebrates from 32 countries on six continents (Duffus et al. 2015).

\subsection{Ranavirus Epidemiology in Amphibians}

Ranavirus infections and related mortality events have been reported in amphibians from North and South America, Europe, Africa, and Asia (Duffus et al. 2015). In North America, 43-57 \% of amphibian mortality events were attributed to viral infections, presumably ranaviruses (Green et al. 2002; Muths et al. 2006). These epidemics usually occurred in mid-to-late summer and involved late stage tadpoles and recent metamorphs (Fig. 1; Green et al. 2002). Mortality is often sudden, with hundreds or thousands of apparently normal larvae present on one day and $>90 \%$ dead within several days (Fig. 2; Green et al. 2002). In one recent report, at least 200,000 larvae died within just $24 \mathrm{~h}$ (Wheelwright et al. 2014). There are similar reports of rapid, seasonal outbreaks in wild amphibians in Europe (e.g., Ariel et al. 2009a; Kik et al. 2011), South and Central America (Fox et al. 2006; Stark et al. 2014), and Asia (e.g., Une et al. 2009), and widespread reports from captive populations that follow similar patterns (Duffus et al. 2015). Price et al. (2014) recently reported declines in amphibian communities at multiple sites in Spain after the apparent introduction of a novel ranavirus. There are, however, several reports of ranavirus being present in larval and post-metamorphic amphibians without notable disease or mortality (Duffus et al. 2015), although most studies do not collect longitudinal data and are liable to miss mortality events (Gray et al. 2015). It is worth noting that sublethal infections by ranavirus can impact fitness-related traits such as growth and development (Echaubard et al. 2010). 


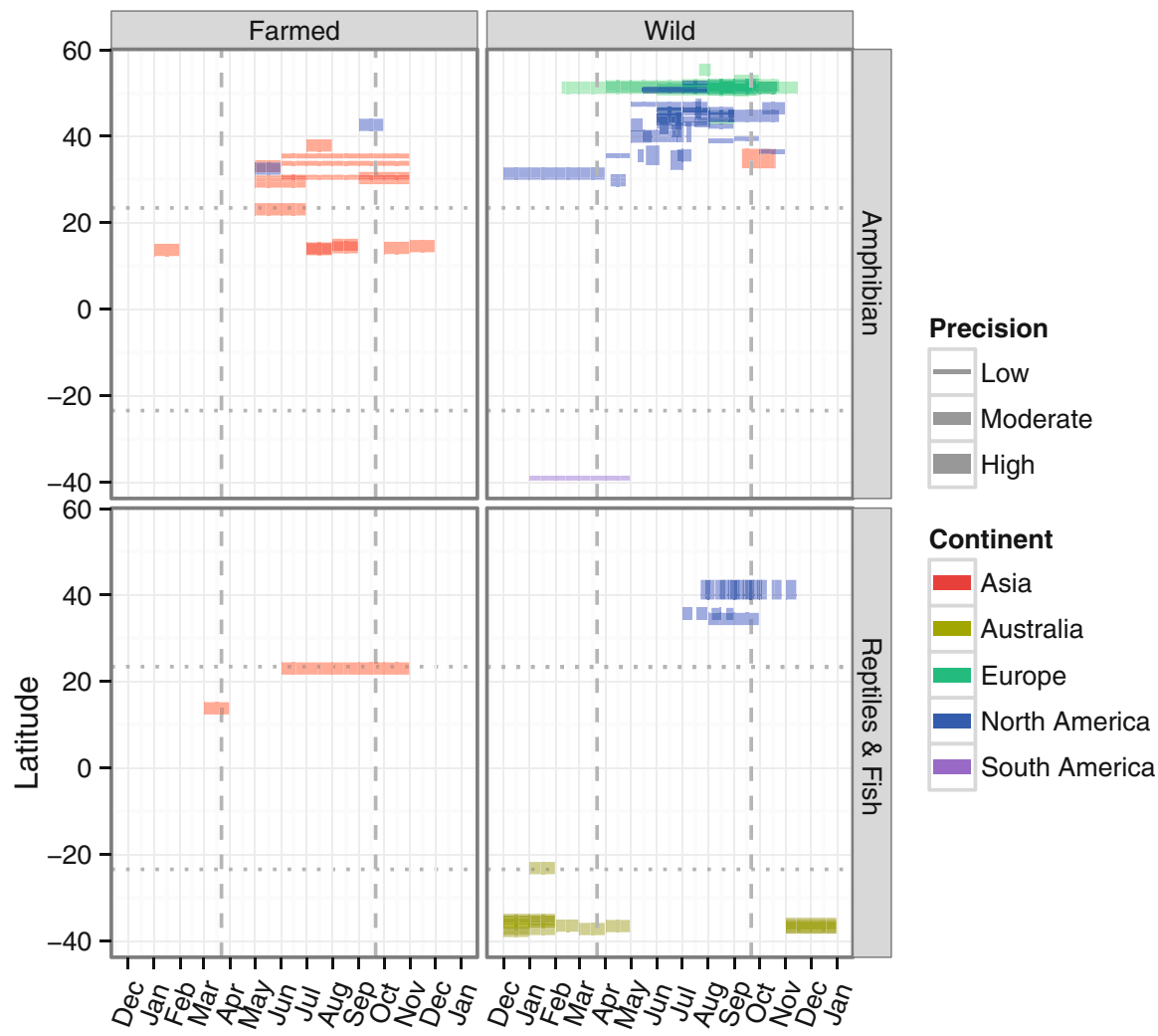

Fig. 1 The seasonal timing of ranavirus die-offs in farmed and wild populations of amphibians, fish, and reptiles (dashed lines) plotted against latitude. Most die-off events begin (and often end) during the summer months. The vertical dashed lines are the equinoxes and the horizontal dashed lines show the tropics of Cancer and Capricorn. The data include 109 events reported in 40 publications that included both the timing and location of the die-off. When only the names of months were provided, we include the entire month(s). If a duration was provided, we adjusted the end dates to match the duration. "Mid" month was assumed to be the 15th. Precision in the description of the dates ranged from low, when only partial information was presented (e.g., the onset, but not end of the event), to high, where precise dates were provided. There is also imprecision in the latitude of many events as reports often provided only county, state, or province data. In these cases, we used the approximate midpoint of the region

In contrast to this general pattern of ranavirus outbreaks in larval amphibians, the ranavirus die-offs in common frogs (Rana temporaria) in the UK seem to be restricted mostly to adult frogs (Cunningham et al. 1993; Teacher et al. 2010; Duffus et al. 2013). Duffus et al. (2013) detected ranavirus in only one of 288 tadpoles collected in one year, but 32 of 120 adults were positive for ranavirus over three years. Population declines in the adult common frogs have been slow, but widespread in the UK (Teacher et al. 2010). 

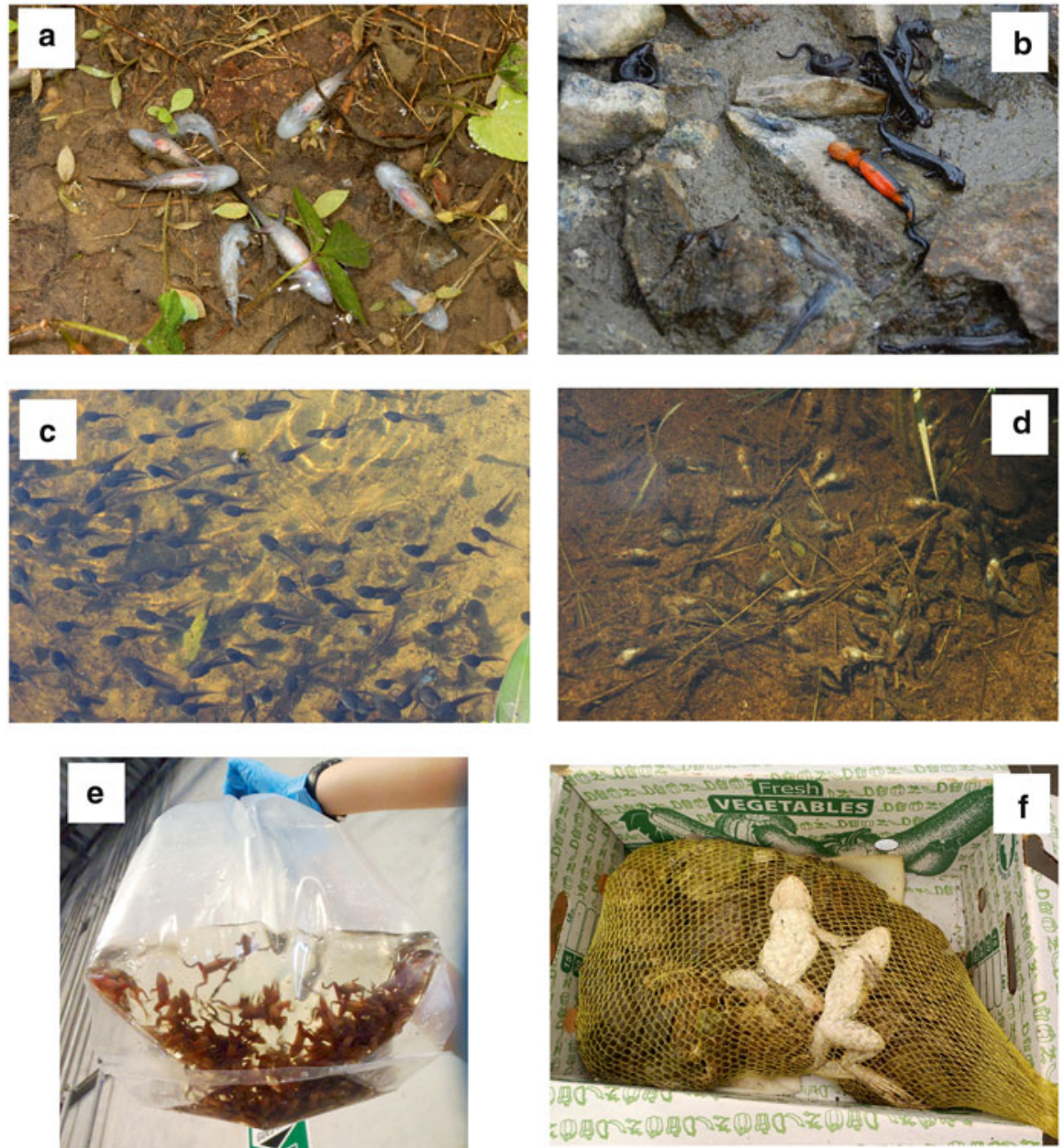

Fig. 2 Ranavirus die-offs can include larval $(\mathbf{a}$, credit=Matthew Niemiller $)$ and adult $(\mathbf{b}$, credit= Ana Balseiro) age classes in amphibians. Outbreaks can occur rapidly progressing from no apparent death $(\mathbf{c}$, credit $=$ Nathaniel Wheelwright $)$ to complete mortality $(\mathbf{d}$, credit $=$ Nathaniel Wheelwright) in a matter of days. Global transport of subclinically infected individuals may be contributing to the emergence of ranaviruses (e, credit $=$ Jonathan Kolby). High contact rates with abundant hosts in captivity and during transport may be resulting in evolution of ranavirus virulence (f, credit $=$ Jonathan Kolby)

\subsection{Ranavirus Epidemiology in Fishes}

Many ranaviruses have been associated with mortality events in cultured fish (e.g., Ahne et al. 1997; Chua et al. 1994; Deng et al. 2011; Langdon et al. 1988; Prasankok et al. 2005; Qin et al. 2003), but the epidemiology and ecology of these aquacultural 
systems is rarely well documented. Most of what is known about the ecology and epidemiology of ranaviruses in fishes comes from studies of Epizootic haematopoietic necrosis virus (EHNV) in Australia and largemouth bass virus (LMBV; a strain of Santee Cooper ranavirus) in the Southeast USA (Whittington et al. 2010). EHNV outbreaks have caused rapid (2-3 weeks) die-offs affecting tens to thousands of juvenile redfin perch (Perca fluviatilis) in the early summer, with a few adults also affected (Langdon et al. 1986; Langdon and Humphrey 1987). In isolated ponds with no prior history of EHNV, die-offs involved mass mortality in adults ( $>1$ year old), suggesting a role of prior exposure or ontogeny. While die-offs are dramatic and have continued over the last 30 years, the frequency with which EHNV epidemics occur is difficult to assess given uncertain detection in deep waters and remote locations (Whittington et al. 2010). EHNV has also caused mortality events in farmed rainbow trout (Oncorhynchus mykiss) in Australia, in which the virus is not very infectious, but can be highly virulent (Langdon et al. 1988; Whittington et al. 1994, 1999).

Most LMBV die-offs occur in the summer and involve large $(>30 \mathrm{~cm})$ largemouth bass (Micropterus salmoides; Grizzle and Brunner 2003). While LMBV is sometimes associated with die-offs of thousands of large fish (Plumb et al. 1996; Hanson et al. 2001) and has been associated with the declines in larger, older largemouth bass noted in the 1990s in some lakes (Maceina and Grizzle 2006), the incidence of diseased or dying fish is often too low to be noticed (Grizzle and Brunner 2003). Moreover, LMBV is often found in clinically normal animals and at sites with no (observed) history of die-offs (Hanson et al. 2001; Grizzle et al. 2002; Grizzle and Brunner 2003). If there is a common theme to the epidemiology of these two fish ranaviruses, it is that epidemics primarily involve certain susceptible life history stages (EHNV in juveniles and LMBV in adults) during stressful conditions (e.g., warm periods).

Because they represent a distinct phylogenetic lineage within the genus Ranavirus (Qin et al. 2003; Huang et al. 2011), it is worth mentioning the Grouper iridovirus (GIV) and Singapore grouper iridovirus (SGIV). These viruses have caused significant mortality and losses in groupers (Epinephelus spp.) and other finfish in mariculture since the mid-1990s in Southeast Asia (Chua et al. 1994; Qin et al. 2003; Harikrishnan et al. 2010). Few details of the epidemiology of this virus have been reported, but epidemics occur over several weeks (Nagasawa and Cruz-Lacierda 2004), cause up to $90 \%$ mortality, and stress (e.g., handling stress, water quality) may play a role in magnifying clinical signs and mortality (Chua et al. 1994).

\subsection{Ranavirus Epidemiology in Reptiles}

In reptiles, ranavirus infections have been detected sporadically, primarily in rehabilitation facilities and other captive settings (Ariel 2011; Allender et al. 2013a; Chinchar and Waltzek 2014). While several outbreaks in free-ranging chelonians have been observed (Allender et al. 2006; Johnson et al. 2008; Belzer and Seibert 
2011; Farnsworth and Seigel 2013), there are no similar reports of ranaviruses in free-living populations of other reptile taxa. Unlike in fish and amphibians, ranavirus outbreaks in chelonians, at least in North America, are more diffuse. Mortalities are observed over the entire active season (i.e., when turtles are not hibernating in winter), often for several years (Belzer and Seibert 2011; Farnsworth and Seigel 2013). Most cases, however, are noted in the summer months (Fig. 1). The available evidence suggests that ranaviruses cause an acute, rapidly lethal infection in chelonians (Johnson et al. 2007). Most individuals that are infected will die within several weeks, so the prevalence of infection at any given point in time is low. For instance, 15 of $71(21 \%)$ free-ranging eastern box turtles (Terrapene carolina carolina) died during a ranavirus die-off at a private nature sanctuary in Pennsylvania, USA (Johnson et al. 2008; Belzer and Seibert 2011). The following year only one of the 55 surviving turtles was seropositive, strongly suggesting that the vast majority of infected individuals died (Johnson et al. 2010). Similarly, Allender et al. (2013a) found that the prevalence of ranavirus infection was very low $(1 / 309 ; 0.3 \%)$ over 3 years in free-ranging eastern box turtles in Tennessee, USA. The seroprevalence of free-ranging gopher tortoises (Gopherus polyphemus) from five states in the southeastern USA was also low (1.5\%; Johnson et al. 2010), which is consistent with a highly virulent, acute infection. There is some evidence that ranavirus infections in more aquatic turtles may be less pathogenic (Sect. 7). Consistent with this hypothesis, ranavirus prevalence was higher $(11 / 63 ; 17 \%)$ in highly aquatic eastern painted turtles (Chrysemys picta picta) in Virginia, USA (Goodman et al. 2013).

Based on the available information, it appears unlikely that the sporadic mortality events in chelonians are caused by self-sustaining ranavirus epidemics. Ranaviruses infections in chelonians are acute and often lethal, which provides little time for infected turtles to contact naïve turtles. Moreover, most chelonian populations exist at low densities, which further limits opportunities for transmission. These die-offs therefore likely occur from spillover of ranavirus infections from other species.

\subsection{Summary of Ranavirus Epidemiology}

While there is still a great deal of uncertainty surrounding ranavirus epidemiology in natural populations, two patterns are apparent. First, there appears to be a common temporal pattern to ranavirus epidemics or mortality events, at least in fish and amphibians (Fig. 1). Die-offs have a rapid onset, generally in the summer months, and often progress rapidly, although there are important exceptions to this pattern (e.g., bullfrog [Lithobates catesbeianus (formerly Rana catesbeiana)] die-offs in Japan and the American Southeast have been noted in October; Hoverman et al. 2012; Une et al. 2009). Second, there is a great deal of variability in the outcome of ranavirus epidemics between populations and locations, from no (apparent) mortality to die-offs with few survivors. In the next sections, we explore several hypotheses for these patterns, beginning with the timing of epidemics. 


\section{Explanations for the Apparent Seasonality of Ranavirus Epidemics}

Ranavirus epidemics often occur during late spring or summer and can begin and end within weeks (Langdon and Humphrey 1987; Green et al. 2002; Grizzle and Brunner 2003). There are four non-mutually exclusive hypotheses that might explain the apparent seasonality and rapidity of observed ranavirus die-offs. First, this pattern may be spurious, resulting from a detection bias. Second, the die-offs may simply reflect the underlying epidemic dynamics following the introduction of ranavirus into populations earlier in the year. Third, hosts may become more susceptibility to ranavirus infections at certain development stages that coincide with the summer months. Lastly, these events may occur when temperatures rise in the summer. In the following sections, we evaluate these hypotheses and their underlying mechanisms.

\subsection{Detection Biases}

The frequent observation that ranavirus die-offs involve metamorphosing amphibians and late stage larvae (Green et al. 2002) may simply be an artifact of metamorphs moving to shallow water to complete metamorphosis where they are more easily observed. Similarly, large numbers of juvenile fish tend to cluster near shores frequented by people, which contributed to the first detection of EHNV in redfin perch (Whittington et al. 2010). Die-off events in remote locations, at times when people are not active, and in cryptic species may go unnoticed. For example, morbidity and mortality of turtles due to ranavirus may be often missed given the secretive nature of these animals (Farnsworth and Seigel 2013). However, many ranavirus outbreaks that fit the general pattern of rapid onset of mortality in the summer have been observed in well-studied, frequently visited populations (e.g., Brunner et al. 2011; Langdon and Humphrey 1987; Petranka et al. 2007; Wheelwright et al. 2014), suggesting that detection biases are not a general explanation for the observed timing of mortality events.

\subsection{Seasonal Introductions and Incidence of Ranavirus Infection}

The rapid onset and seasonality of ranavirus die-offs may simply reflect a rapid increase in the incidence of infections following the introduction of virus earlier in the year. One hypothesis is that ranavirus epidemics in amphibians begin when sublethally infected adults return to sites to breed (Brunner et al. 2004). Adults might transmit infections directly to larvae of the same or other species if they overlap in 
space and time, or indirectly if they die from a recrudescent infection and are consumed by feeding larvae. Brunner et al. (2004) found that some adult tiger salamanders (Ambystoma mavortium [formerly tigrinum] nebulosum) in the southwestern USA returning to breeding sites were infected with Ambystoma tigrinum virus (ATV). Similarly, a recent survey found that $39 \%$ of male wood frogs (Lithobates [Rana] sylvaticus) in the eastern USA returning to breeding sites harbored subclinical infections (JLB, E. J. Crespi, and S. Hall, Washington State University; S. Duncan, N.M. Mattheus, and L. Rissler, University of Alabama, unpublished data). Spillover from adults or carcasses could spark subsequent larval epidemics. Thus, the dynamics of ranavirus infection may be similar to those of many other infectious diseases (Keeling and Rohani 2008), spreading slowly after introduction because the infection is rare and accelerating as the epidemic builds. Because ranavirus infections in amphibians are often lethal, usually within days to weeks of exposure in laboratory challenges (Gray et al. 2009a; Hoverman et al. 2011), one would expect mortality to track infection with some relatively short delay. The actual time course of mortality in the wild may appear more rapid simply because those few individuals dying earlier in an epidemic are difficult to detect because they are small, decompose quickly, or are scavenged. Only when there are many dead animals (and perhaps the scavengers are sated) does the event become obvious. Moreover, an accumulation of infectious carcasses may facilitate transmission (Pearman et al. 2004; Harp and Petranka 2006; Brunner et al. 2007), increasing the speed of the epidemic. There is some support of this hypothesis in amphibians. Todd-Thompson (2010) observed a typical epidemic curve in her longitudinal survey for ranaviruses in an amphibian community inhabiting a depressional wetland in the southern Appalachian Mountains of the USA. Ranavirus was not detected until late April, when $20 \%$ of the larvae were infected and increased to a high of $80 \%$ twenty days later, which coincided with a die-off of ambystomatid larvae. The rapid increase in the prevalence of infection signs in spotted chorus frog (Pseudacris clarkii) tadpoles collected by Torrence et al. (2010) is also consistent with this model. Indeed, mortality events generally coincide with high infection prevalence (Bollinger et al. 1999; Greer et al. 2005; Fox et al. 2006; Kik et al. 2011; Hoverman et al. 2012; Homan et al. 2013; Titus and Green 2013).

In some ranavirus-host systems, infection prevalence may be uncorrelated with the occurrence of disease. Greer et al. (2009), for instance, found that ATV infection in tiger salamanders (A. m. nebulosum) increased to a peak of $\sim 50 \%$ prevalence in three ponds in northern Arizona, but no morbidity or mortality was observed. Similarly, Duffus et al. (2008) found that 20-32\% of wood frog tadpoles were infected in early summer, but none showed clinical signs of disease. LMBV is also commonly found in the absence of morbidity or mortality (Hanson et al. 2001; Grizzle and Brunner 2003; Groocock et al. 2008; Southard et al. 2009). It is thus important to collect both epidemiological and demographic data on host populations at multiple time points to understand the effects of ranaviruses on their host populations (Gray et al. 2015). 


\subsection{Susceptibility Throughout Development}

In addition to the frequent observation that juveniles are more susceptible to ranavirus infections than adults (Cullen et al. 1995; Ariel 1997; Cullen and Owens 2002; Bang Jensen et al. 2011b), hosts may become vulnerable to ranavirus infections at certain development stages that coincide with the summer months. In amphibians, die-off events from ranaviruses have often been reported in individuals near to or undergoing metamorphosis (Speare and Smith 1992; Green and Converse 2005; Greer et al. 2005). Amphibian metamorphosis is energetically costly and entails a period of natural immunosuppression (Rollins-Smith 1998; Carey et al. 1999). Metamorphosing anurans are hypothesized to be particularly vulnerable to ranavirus infection. This might explain both the occurrence of ranavirus die-offs in amphibians in the summer and their speed (e.g., Gahl and Calhoun 2010). Warne et al. (2011) found that the odds of death in wood frog tadpoles exposed to ranavirus increased 1.7-fold with each increase in Gosner (1960) development stage. Higher susceptibility of wood frog larvae to ranavirus later in development was supported by an epidemiological model that correctly predicted the timing of mortality events in summer using stage-specific susceptibility (Fig. 3; Warne et al. 2011). If all stages were equally susceptible, mortality in wood frog populations would occur in spring, which was not observed. Haislip et al. (2011) also found that susceptibility to ranavirus differed among amphibian developmental stages, but metamorphosis was not always the most susceptible stage. Thus, the occurrence of metamorphosis is not a universal explanation for timing of ranavirus outbreaks in amphibian communities.

\subsection{Temperature and Susceptibility}

Higher temperatures during summer may be another factor contributing to the timing of ranavirus outbreaks. Grizzle and Brunner (2003) hypothesized that the occurrence of LMBV die-offs in the summer was driven by increased susceptibility of largemouth bass to infection at higher temperatures or other temperature-related stressors (e.g., low oxygen concentrations, Goldberg 2002), which was supported by experimental challenges (Grant et al. 2003). The occurrence of EHNV epidemics in redfin perch in the early summer, primarily in juveniles (Langdon 1989), may also be related to the effects of temperature on susceptibility. Juvenile perch feed in shallow, warmer waters in the early summer, which promotes EHNV infection and disease (Whittington and Reddacliff 1995; Ariel et al. 2009b), while adults feed in deeper, cooler waters and may thus avoid or clear infections (Whittington and Reddacliff 1995; Whittington et al. 2010). Outbreaks of ENHV in rainbow trout in Australia do not appear to be associated with temperature, but rather with poor husbandry and high stocking densities (Whittington et al. 1999, 2010).

Temperature can influence both the kinetics of host-parasite interaction and act as a stressor to hosts. First, the replication rates of pathogens and the kinetics of the 
a
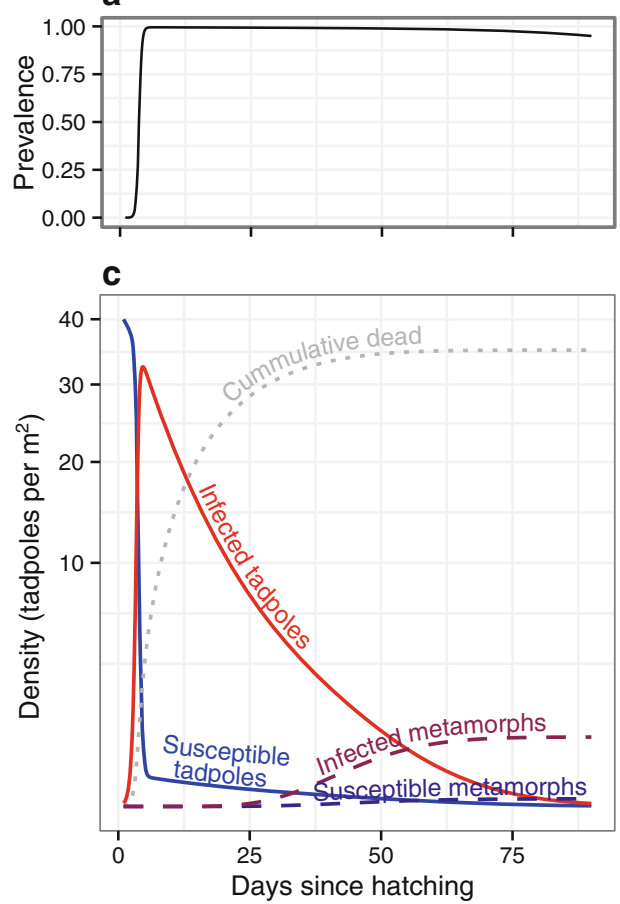

b

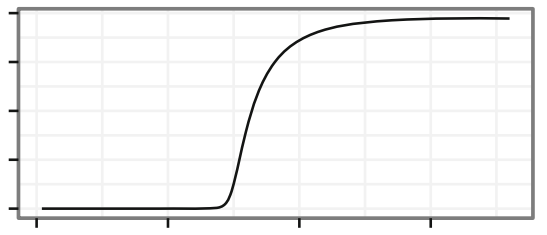

d

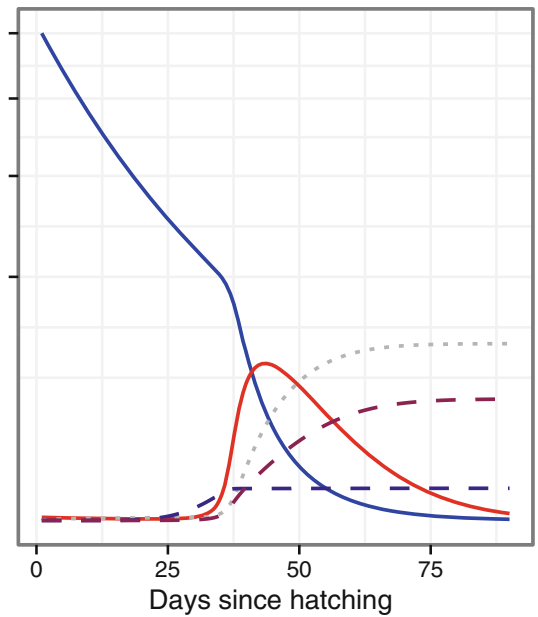

Fig. 3 The prevalence $(\mathbf{a}, \mathbf{b})$ and dynamics $(\mathbf{c}, \mathbf{d})$ of a susceptible-infected-susceptible (SIS) model of ranavirus epidemics in a population of developing wood frog tadpoles that assumes all tadpoles are equally susceptible $(\mathbf{a}, \mathbf{c})$ or that tadpoles become more susceptible to infection as they approach metamorphosis $(\mathbf{b}, \mathbf{d})$. The model includes a constant background mortality rate of 0.04 per day (estimated from DeBenedictis 1974) and a development rate of 0.25 stages per day from Gosner (1960) stage 20 (hatching) to 41 (metamorphosing), which equates to an average larval period of 60 days. The transmission rate was estimated from experimental epidemics in mesocosms with wood frog tadpoles (JLB, Washington State University, unpublished data). The initial density of hatchling tadpoles is 40 per $\mathrm{m}^{2}$, which is at the low end of the natural range of densities (e.g., 26-790 per $\mathrm{m}^{2}$; Petranka et al. 2003), but the results do not qualitatively change at 400 per $\mathrm{m}^{2}$. Estimates of the rates at which infected animals die ( 0.0331 per day) or recover $(0.0169$ per day) were from Reeve et al. (2013). Note that recovered tadpoles become susceptible again in this model, as we have no evidence of immune memory in these tadpoles. Stage-specific susceptibility was included by multiplying the transmission term by the Gosner stage-specific odds of becoming infected, which was estimated in an $\mathrm{LD}_{50}$ study in Warne et al. (2011)

host's immune responses can be temperature sensitive (Altizer et al. 2013). Ariel et al. (2009b) reported that ranavirus replication rates in cell culture increased with temperature up to some optimum, which varied by virus isolate and cell line, but generally was between 24 and $28{ }^{\circ} \mathrm{C}$. However, the short-finned eel ranavirus (SERV) isolated from a coldwater eel replicated best at $20{ }^{\circ} \mathrm{C}$ or lower, suggesting adaptation to its host's environment (Ariel et al. 2009b). Grant et al. (2003) also found some evidence for a host-specific temperature profile in LMBV replication. 
While LMBV grew slightly faster at $30{ }^{\circ} \mathrm{C}$ than $25^{\circ} \mathrm{C}$, it did not replicate past one day in cell culture when held at $35^{\circ} \mathrm{C}$, probably because largemouth bass typically inhabit aquatic systems that do not exceed $30^{\circ} \mathrm{C}$ (Eaton and Scheller 1996; Grant et al. 2003). Thus, there is strong evidence that ranavirus replication is highly temperature- and host-dependent (Speare and Smith 1992; Grant et al. 2003; Rojas et al. 2005; Ariel et al. 2009b).

To the extent that replication in vitro represents replication rates in vivo, we would expect that the rates of viral replication and host mortality would generally increase with temperature. Results from several studies are consistent with this hypothesis. In experimental water bath challenges of adult redfin perch, all of the fish held at water temperatures of $12-21{ }^{\circ} \mathrm{C}$ died, while those at $6-10{ }^{\circ} \mathrm{C}$ either did not become infected or quickly cleared the infection (Whittington and Reddacliff 1995). Experimental challenges of European stocks of redfin perch and rainbow trout with EHNV also found that mortality increased with temperature (from 15 to $20^{\circ} \mathrm{C}$ ), and significant mortality was not observed at $10^{\circ} \mathrm{C}$ (Ariel and Jensen 2009). Similarly, Bayley et al. (2013) reported $>96 \%$ mortality of the common frog tadpoles exposed to ranaviruses (FV3 [Frog virus 3] or REV [Rana esculenta virus]) at $20{ }^{\circ} \mathrm{C}$ but $<32 \%$ when exposed to ranaviruses at $15^{\circ} \mathrm{C}$. A contrasting pattern was observed in a study conducted with larval tiger salamanders and ATV (Rojas et al. 2005). Larvae exposed to ATV and reared at 10 or $18{ }^{\circ} \mathrm{C}$ experienced $>80 \%$ mortality, while larvae reared at $26{ }^{\circ} \mathrm{C}$ experienced $<38 \%$ mortality. Viral titers were higher in salamanders that died at $10^{\circ} \mathrm{C}$ than $18^{\circ} \mathrm{C}$, suggesting that colder temperature may have suppressed immune responses to ATV. There is also evidence in turtles that temperature influences the outcome of infection. Red-eared sliders (Trachemys scripta elegans) infected with FV3 experienced $100 \%$ mortality at $22{ }^{\circ} \mathrm{C}$ but $50 \%$ mortality at $28{ }^{\circ} \mathrm{C}$ (Allender et al. 2013b). Additionally, time to death was shorter and viral loads greater in turtles at $22{ }^{\circ} \mathrm{C}$ compared to those at $28^{\circ} \mathrm{C}$. Allender et al. (2013b) hypothesized that cell-mediated or humoral immune responses could be enabling turtles to clear infections at higher temperatures.

Instead of focusing on the kinetics of viral replication and host immune responses, temperature could be a stressor in and of itself. Bayley et al. (2013) found greater mortality in $R$. temporaria tadpoles held at $20{ }^{\circ} \mathrm{C}$ than at $15{ }^{\circ} \mathrm{C}$ when exposed to FV3, PPIV (Pike perch iridovirus), and REV, but mortality was also greater at $20^{\circ} \mathrm{C}$ in the unexposed control animals, suggesting that the higher temperature was generally stressful. Several fish challenges have shown increased mortality at temperatures near the fishes' thermal limits (Whittington and Reddacliff 1995; Grant et al. 2003). Ariel and Jensen (2009) noted that mortality in rainbow trout exposed to EHNV was highest at $20^{\circ} \mathrm{C}$, which is beyond the natural temperature range for this species and likely stressful or immunosuppressive. The redfin perch in their study, however, experienced the greatest mortality at intermediate temperatures-twice as much at $15{ }^{\circ} \mathrm{C}$ than $20^{\circ} \mathrm{C}$, and very little at $10{ }^{\circ} \mathrm{C}$-so temperature-induced stress appears not to be important in this species. Perhaps viral replication was favored at $15^{\circ} \mathrm{C}$ more than the host's immune system, whereas the immune system was dominant at $20^{\circ} \mathrm{C}$ (Ariel and Jensen 2009). Similarly, Echaubard et al. (2014) found that the rate of mortality in experimental epidemics with northern leopard frog and wood 
frog tadpoles was greater at $14{ }^{\circ} \mathrm{C}$ than at $22{ }^{\circ} \mathrm{C}$ in control populations and those exposed to two FV3-like ranaviruses, providing additional evidence that temperature can influence ranavirus epidemics, but likely depends on the host and type of virus (Echaubard et al. 2014). In conclusion, there are likely multiple mechanisms through which temperatures can influence ranavirus infections. Given the predicted increases in global temperature with climate change, a greater focus on understanding the interactive effects of temperature and its variability (and even temperature variability; e.g., Raffel et al. 2006; but see Terrell et al. 2013) on host and pathogen physiology is needed (Altizer et al. 2013).

\section{Susceptibility in the Face of Other Natural and Anthropogenic Stressors}

One of the perplexing characteristics of ranavirus epidemics is the variation in the outcome, from no (apparent) mortality to massive die-offs. This apparent "randomness" has led to the hypothesis that environmental factors, which can vary a great deal in space and time, may play an important role in disease outbreaks (Gray et al. 2009a). Natural and anthropogenic stressors are broadly thought to suppress immune function, making individuals in stressful environments more susceptible to infection and disease (reviewed in Martin 2009; Blaustein et al. 2012). Although many researchers use the term "stress" to mean any aversive, generally unpredictable condition that would seem to challenge the organisms, there is a physiological basis to the "stress-induced susceptibility" hypothesis. It posits that chronically elevated levels of glucocorticoid "stress" hormones have negative impacts on the immune system, such as reducing circulating lymphocyte populations, decreasing cytokine production, or suppressing cell-mediated immune responses (Sheridan et al. 1994; Haddad et al. 2002; Dhabhar 2009).

Defining stress and identifying stressors and the responses they elicit a priori, however, is often difficult, particularly in the absence of detailed information on the environmental, developmental, and evolutionary context of the organisms (Martin 2009). For example, Warne et al. (2011) found that pro-metamorphic wood frog tadpoles challenged with a ranavirus had elevated glucocorticoid concentrations relative to controls and also experienced faster development and more rapid weight loss. As glucocorticoids are responsible for mobilizing resources (e.g., to respond to infection) as well as accelerating metamorphosis in pro-metamorphic tadpoles, the authors hypothesized that this surge in glucocorticoids led to an energetic trade-off. Only those individuals with large enough energetic reserves could support rapid development and a robust immune response at the same time (Warne et al. 2011). Clearly, linking elevated glucocorticoid concentrations to immunocompetence is fraught with difficulties, even with considerable context. It is thus not surprising that the reported effects of natural and anthropogenic stressors on host susceptibility to ranaviruses are highly variable. 


\subsection{Predators and Other Natural Stressors}

Decades of research, especially in amphibians, have demonstrated that predators can alter the physiology, behavior, and morphology of individuals and populations (Tollrian and Harvell 1999). The threat of predation can alter the production of the stress hormone corticosterone in tadpoles (Fraker et al. 2009), and thus presumably their immunocompetence. Recently, several studies have examined the influence of predation risk on disease outcomes using caged predators, which emit chemical cues (i.e., kairomones), but prevent the predator from contacting and killing the prey. Kerby et al. (2011) found that infection prevalence and mortality increased in ATVexposed larval tiger salamanders when exposed to chemical cues from larval dragonfly predators (Anax junius) compared to controls. However, Haislip et al. (2012) found no effect of predator cues on mortality or infection in a similar set of experiments with four species of larval anurans (L. clamitans, L. sylvaticus, P. feriarum, and Hyla chrysoscelis) and two predator species (Anax sp. and Belostoma flumineum). Similarly, Reeve et al. (2013) found no effect of caged predators (dytiscid beetle larvae and dragonfly larvae) on mortality rates of wood frog tadpoles in laboratory or mesocosm experiments. In this experiment, glucocorticoid concentrations did not differ between the control and predator cue treatments, suggesting either that predator stress does not universally elevate corticosterone production or that the effect dissipates with time. Thus, it seems that predators do not make anuran larvae more susceptible to ranavirus infection, although studies with additional species would be helpful. In addition, although other putative stressors, such as food-level reductions significantly increased glucocorticoid concentrations, tadpoles were not more likely to become infected or experience ranavirus-induced mortality (Reeve et al. 2013). Thus even energetically challenged, physiological stressed amphibians may not be more susceptible to ranaviruses.

\subsection{Anthropogenic Stressors}

It has been hypothesized that anthropogenic stressors may have a stronger impact on ranaviral disease than natural stressors (Reeve et al. 2013). Indeed, many emerging infectious diseases have been linked to human activity, including land-use change and pollution (Daszak et al. 2001). St-Amour et al. (2008) found that the prevalence of ranavirus infection in green frog (Lithobates [Rana] clamitans) populations increased with proximity to industry and human housing, although the mechanisms were unclear. Several studies have found increased ranavirus prevalence in wetlands used by cattle, which were attributed to reductions in emergent vegetation, resulting in greater clustering of amphibian larvae, and decreased water quality (Gray et al. 2007; Greer and Collins 2008; Hoverman et al. 2012). Gahl and Calhoun $(2008,2010)$ found that the probability of ranavirus outbreaks increased, albeit weakly, in ponds with higher concentrations of aluminum ions, low levels of 
calcium, higher temperatures, and those at higher elevation in the watershed. A long-term study in the Great Smoky Mountains National Park, USA, found that ranavirus prevalence was greater in plethodontid salamanders at lower elevation, which the authors attributed to higher water temperature, greater human access, and possibly downstream flow of virions (Gray et al. 2009b; Sutton et al. 2014). Despite these intriguing results from correlational studies, there is a need for experimental studies that investigate the relative importance of anthropogenic stressors and identify the underlying mechanisms.

Pesticides are another anthropogenic factor that may influence the likelihood of developing ranaviral disease. Aquatic systems can receive pesticides from direct application, terrestrial runoff, or windborne drift (Davidson et al. 2002). Moreover, many pesticides have immunosuppressive effects on wildlife (Marcogliese and Pietrock 2011). Larval tiger salamanders exposed to the herbicide atrazine had reduced peripheral leukocyte counts and experienced increased susceptibility to ATV infection (Forson and Storfer 2006b). The insecticides chlorpyrifos and carbaryl also increased mortality of ATV-exposed tiger salamanders (Kerby and Storfer 2009; Kerby et al. 2011). However, Forson and Storfer (2006a) found that atrazine in the water reduced ATV infection in larval long-toed salamanders (Ambystoma macrodactylum). The authors hypothesized that the pesticide may have inactivated the virus or that the pesticide stimulated the immune system of the host. In all four studies, exposure to pesticides and ranavirus occurred simultaneously. Because the immunosuppressive effects of pesticides can take several days to manifest, experimental designs that initiate pesticide exposure prior to virus addition may reveal more consistent outcomes.

\section{Ranavirus Transmission Within a Species}

Ranaviruses can be transmitted by contact with infected individuals, through the water or on fomites (e.g., pond substrates), and by consuming part or all of infected animals (Langdon et al. 1988; Reddacliff and Whittington 1996; Jancovich et al. 1997; Plumb and Zilberg 1999b; Woodland et al. 2002b; Pearman et al. 2004; Harp and Petranka 2006; Brunner et al. 2007; Cunningham et al. 2007a; Robert et al. 2011; Brenes et al. 2014a). Viral mRNA is detectable in the intestines of larval and adult African clawed frogs (Xenopus laevis) as early as $3 \mathrm{~h}$ after exposure to virus in water and then spreads to other tissues, suggesting that the intestines are a primary point of entry of waterborne virus in amphibians (Robert et al. 2011). The skin may not be a common site of infection in metamorphosed amphibians because they secrete antimicrobial peptides on their skin, which can inactivate several types of pathogens, including FV3 and ATV (Chinchar et al. 2001, 2004; Sheafor et al. 2008; Rollins-Smith 2009). Brunner et al. (2007), however, demonstrated that a 1 s skinto-skin contact out of water was sufficient for transmission of ATV from infected, symptomatic tiger salamander larvae to uninfected larvae, so entry through the epithelium is possible at least during the larval stage. 
We suspect that consuming infected tissues is a common and important route of transmission in amphibian larvae. Cannibalism is common in amphibians and reptiles (Crump 1983; Polis and Myers 1985). Even anuran tadpoles engage in cannibalism and scavenging (Altig et al. 2007). Two studies found that wood frog and Italian agile frog (Rana latastei) tadpoles had greater mortality rates when allowed to scavenge dead FV3-infected conspecifics (Pearman et al. 2004; Harp and Petranka 2006). Similarly, Brunner et al. (2007) found that ATV-infected tiger salamander larvae were most infectious near or after death when they could be easily consumed.

The absence of gastrointestinal lesions in fish intraperitoneally injected with EHNV but their occurrence in naturally infected fish suggests an oral route of infection in nature (Langdon et al. 1988; Reddacliff and Whittington 1996). The LMBV is also transmissible through the water (Plumb and Zilberg 1999b) and by consuming infected prey (Woodland et al. 2002a). Transmission by direct contact may also be possible, as LMBV has been detected in cutaneous mucus (Woodland et al. 2002b). In an experiment by Grant et al. (2005), LMBV was transmitted from infected to naïve fish in small aquaria nearly as efficiently when direct contact was prevented as when it was allowed, suggesting that transmission through water is the dominant route. One caveat is that while outbreaks of LMBV disease primarily involve adults, most transmission studies used juvenile fish.

The route of transmission to chelonians is less clear. Johnson et al. (2007) could only induce infections in a box turtle (Terrepene ornata ornata) and several redeared sliders with intramuscular injections of Burmese star tortoise ranavirus, but those that were orally exposed to the same dose remained uninfected. More recently, however, Brenes et al. (2014a) demonstrated water-borne transmission of an FV3like ranavirus isolated from pallid sturgeon (Scaphirhynchus albus; Waltzek et al. 2014) to red-eared sliders: $20 \%$ of turtles that were bath exposed and $30 \%$ of turtles co-housed with infected Cope's gray treefrog $(H$. chrysoscelis) became infected. It should also be noted that transmission by arthropod vectors has not been ruled out. The frog erythrocytic virus, which appears to be an iridovirus but likely not a ranavirus (Gruia-Gray et al. 1989), was mechanically transmitted between metamorphosed bullfrogs by Culex territans mosquitos and the midge, Forcipomyia (Lasiohelea) fairfaxensis (Gruia-Gray and Desser 1992). Allender et al. (2006) speculated that ranaviruses may be transmitted between chelonians by vectors because the virus is found in circulating blood cells in turtles. Kimble et al. (2014) recently detected ranavirus in mosquitoes at a site with ranavirus-infected eastern box turtles. Mosquito transmission might help explain how ranaviruses continue to spread between turtles that rarely encounter one another and die fairly quickly from infection.

Different routes of transmission likely result in individuals being exposed to different amounts of virus, which can have dramatic effects on the probability and outcome of infection. Dose-response experiments in fish and amphibians have demonstrated that exposure to larger doses of ranavirus leads to an increased probability of infection and death with reduced survival time (Plumb and Zilberg 1999b; Pearman et al. 2004; Brunner et al. 2005; Deng et al. 2011; Warne et al. 2011). Consuming infected tissues, which likely exposes hosts to a greater dose of 
virus, is thus expected to increase the chance of infection compared with a single contact or swimming through contaminated water. Consistent with this hypothesis, Hoverman et al. (2010) found that tadpoles that were orally inoculated with FV3like viruses died faster than those exposed via water bath. Although rarely evaluated in an ecologically relevant context, there may be a minimum dose necessary to cause infection and disease (e.g., $10^{2} \mathrm{PFU} \mathrm{mL}^{-1}$ in tiger salamander larvae) and a threshold above which dose becomes unimportant (e.g., $>10^{4} \mathrm{PFU} \mathrm{mL}^{-1}$; Brunner et al. 2005). It is important to note that even within highly standardized exposures, the course and outcome of infections can vary greatly (e.g., Beck et al. 2006).

Lastly, we are aware of no published studies on ranavirus transmission rates or dynamics in wild populations. Virtually every study on transmission focuses on the routes by which ranavirus can be transmitted, ignoring the critical role that host behavior, density, and contact rates may play in shaping transmission dynamics. One problem is a lack of longitudinal data. That is, studies that track the incidence of ranavirus infection and mortality over time are rare (Gray et al. 2015). A focus on collecting the data that could be used to parameterize epidemiological models would significantly advance our understanding of ranavirus ecology (Gray et al. 2015).

\section{Ranavirus Transmission Between Species}

It is clear that ranaviruses can infect a wide range of hosts (Duffus et al. 2015), but until recently it was unclear whether these viruses were restricted to certain closely related taxa or could be transmitted between classes of ectothermic vertebrates. Anecdotal evidence from the wild suggested the possibility of interclass transmission. For example, morbid fish and turtles have been reported in association with amphibian die-offs due to ranaviral disease (Mao et al. 1999; Farnsworth and Seigel 2013). Moreover, several laboratory studies have demonstrated that BIV and FV3like viruses isolated from one vertebrate class could be used to experimentally infect animals in another (Moody and Owens 1994; Ariel and Owens 1997; Bang Jensen et al. 2009, 2011b; Gobbo et al. 2010; Bayley et al. 2013; Brenes et al. 2014b). Recently, Brenes et al. (2014a) paired ranavirus-exposed and -unexposed hosts from different vertebrate classes on opposite sides of a fine mesh screen, preventing direct contact but allowing water and virions to pass through. They demonstrated that redeared slider hatchlings and western mosquito fish (Gambusia affinis) were able to transmit an FV3-like ranavirus to Cope's gray treefrog tadpoles, resulting in $50 \%$ and $10 \%$ mortality, respectively. Treefrog tadpoles infected $30 \%$ of red-eared sliders (although no mortality occurred in the 28-day experiment), but none of the mosquito fish. While it is important to demonstrate that interclass transmission is possible, the more important question may be understanding how individuals of different classes contact (or consume) one another in ways that promote direct transmission or overlap in space and time so that indirect transmission can occur (Gray et al. 2009a). 


\section{Susceptibility to Ranaviruses Among Species}

There are a growing number of experimental studies investigating the relative susceptibility of amphibian species to ranavirus infection and disease (Cullen et al. 1995; Cullen and Owens 2002; Schock et al. 2008; Hoverman et al. 2010, 2011; Haislip et al. 2011). Until the recent studies by Brenes et al. (2014a, b), comparative studies involving reptiles were generally lacking, and those involving fish are largely restricted to EHNV (Becker et al. 2013; Langdon 1989; but see Brenes et al. 2014b). Note, however, that several recent studies have exposed different fish species to multiple ranaviruses from fish and amphibians, so collectively information is accumulating on the relative susceptibility of fish (Bang Jensen et al. 2009, 2011a; Gobbo et al. 2010; Brenes et al. 2014b).

From these studies, two patterns seem to emerge. First, species vary a great deal in susceptibility to any given ranavirus. For instance, Becker et al. (2013) challenged 12 economically and ecologically important freshwater fish in Australia with EHNV. Four were susceptible, one (the eastern mosquitofish, G. holbrooki) was a potential carrier, and seven either did not become infected or recovered from infection (Becker et al. 2013). Similarly, the outcome of exposure to an FV3-like ranavirus varied dramatically among 14 anurans and five caudates from North America, from complete mortality to no infections detected at the end of the experiment (Hoverman et al. 2010, 2011; Haislip et al. 2011). Challenges with three FV3-like ranaviruses isolated from a chelonian, fish, and anuran resulted in infection in only two of five fish species (including the western mosquitofish) and two of three highly aquatic turtles (Florida softshell turtle, Apalone ferox, and Mississippi map turtle, Graptemys pseudogeographica kohni; Brenes et al. 2014b). In addition to differences among host species, it is clear that susceptibility varies among developmental stages and environmental conditions (Sect. 3.3). So while we often speak of the susceptibility of fish or frogs to ranaviruses or treat all ranaviruses as very similar, it is increasingly clear that such broad statements mask a great deal of important variation. Explaining this variation remains a challenge.

In a promising step forward, Hoverman et al. (2011) used a comparative phylogenetic approach with 19 amphibian species from seven families to assess possible correlates (e.g., phylogenetic relatedness, life history, ecology) of susceptibility to ranavirus (FV3) infection. Certain families (Ranidae) were more susceptible on average than others (Hylidae and Ambystomatidae), but there were also patterns related to ecology and life history. Species that breed in semi-permanent wetlands and have limited distributions (i.e., rare species) were more susceptible to infection. Additionally, there was evidence that species with rapidly developing larvae were more susceptible to infection. This result could be driven by life history trade-offs such that investment in growth and development comes at the cost of defense against pathogens. Such a trade-off has been observed with trematode infections in amphibians (Johnson et al. 2012), and it is clear that ranavirus infections do impart costs in terms of growth and development (Echaubard et al. 2010). 
Given this interspecific variation in susceptibility (and, presumably, differences in shedding rates and behavior), community composition is likely to influence the likelihood, dynamics, and outcome of ranavirus outbreaks. Species that amplify pathogen transmission increase the likelihood of an outbreak occurring (Paull et al. 2012). Moreover, the order in which host species are exposed to the pathogen may change outcomes. Brenes (2013) demonstrated in aquatic mesocosms that, if wood frog tadpoles were exposed to ranavirus first, community-level mortality was greater than if upland chorus frog ( $P$. feriarum) or spotted salamander (A. maculatum) larvae were exposed first. Additionally, if the community was composed of three highly susceptible species, community-level morality was greater than if it was composed of only one highly susceptible species (Brenes 2013).

The second general pattern of susceptibility is that, despite their generally broad host ranges, ranaviruses appear to be better at infecting animals in the taxonomic class from which they were isolated. In particular, it appears that fish and at least some reptiles are less susceptible to ATV and FV3-like ranaviruses than amphibians (Jancovich et al. 2001; Picco et al. 2010; Allender et al. 2013b; Brenes et al. 2014a). Several studies have demonstrated little or no transmission of ATV (Jancovich et al. 2001; Picco et al. 2010) and FV3 to fish (Ariel et al. 2010; Gobbo et al. 2010; Bang Jensen et al. 2011a; but see Bang Jensen et al. 2011b). Similarly, amphibians may be less susceptible to fish ranaviruses. Bayley et al. (2013) found that the European common frog could be infected with FV3 and REV as tadpoles and adults (and with PPIV as tadpoles), but not with several other fish viruses (doctorfish virus, European sheetfish virus, guppy virus 6, EHNV, and SERV). Distinctions in host range may be found even within species of ranavirus. For example, the turtles in Brenes et al. (2014b) developed subclinical infections with FV3-like viruses isolated from a fish and turtle, but none were infected by the frog isolate. We caution against extrapolating these patterns too broadly, however. Researchers have only begun to sketch the host ranges of ranaviruses, so it remains an open question whether the patterns described above are general, and if so, why.

\section{Persistence of Ranaviruses in the Environment and Carriers}

There are two potential mechanisms of persistence of ranaviruses: enduring in the environment or in sublethally infected hosts (reservoirs). Historically, ranaviruses were thought to be resistant to degradation in the environment. For instance, EHNV can persist in fish tissues frozen at -20 and $-70{ }^{\circ} \mathrm{C}$ for more than 2 years and for at least 7 days at $4{ }^{\circ} \mathrm{C}$ (Langdon 1989). EHNV is also persistent for long periods in distilled water (i.e., no decrease in titer over 97 days at $15{ }^{\circ} \mathrm{C}$ ) and in tissue culture medium dried on sterile plastic Petri dishes (between 113 and 200 days at $15^{\circ} \mathrm{C}$ in the dark; Langdon 1989). Similarly, LMBV persists in frozen tissues for 155 days (Plumb and Zilberg 1999a). However, ranaviruses degrade more quickly under more ecologically realistic conditions. In one study, LMBV lost $90 \%$ of its infectivity in water in 
$24 \mathrm{~h}$ (its T-90 value), although it remained detectable in water for at least 7 days (Grizzle and Brunner 2003). Nazir et al. (2012) found that four FV3-like viruses isolated from frogs, a tortoise, and a gecko had T-90s of between 22 and 34 days in unsterile pond water at $20^{\circ} \mathrm{C}$ and up to 72 days at $4{ }^{\circ} \mathrm{C}$, which is long enough to allow for continued transmission from the environment within an epidemic, if not between years. However, their experiment isolated virus particles from the direct action of microbes, which is problematic because bacteria and other microbes might otherwise be able to consume and inactivate pathogens. To address this issue, Johnson and Brunner (2014) collected water from five ponds and either filter-sterilized it, UV-disinfected it, or left if unmanipulated then added an FV3-like ranavirus directly to the water. They found the T-90 value in filter-sterilized water was 8 days and only 1 day in the unmanipulated pond water where aquatic microbes were present. Similarly, rapid degradation of ranavirus was observed in spring water when the common zooplankton Daphnia pulex were added to virus-inoculated water. Johnson and Brunner (2014) concluded that while ranaviruses may be resistant to adverse conditions (e.g., drying, freezing), they are likely rapidly degraded in water by naturally occurring microbes and zooplankton, suggesting direct routes of transmission (i.e., contact, ingestion) may be more important than waterborne transmission. An important caveat is that all of these studies used virus grown in cell culture; ranaviruses shed in mucous, sloughed skin, etc., may be protected from microbes and the environment.

Nazir et al. (2012) also tested the persistence of ranaviruses in soil and found T-90s of 30-48 days, which raises concern over the potential for ranaviruses to be translocated in contaminated soil (Harp and Petranka 2006). Brunner et al. (2007), however, found that ATV becomes noninfectious in pond substrate that is allowed to dry. Thus, whether water bodies or their substrate remain hydrated may be critical.

Ranaviruses can persist within infected hosts, whether dead or alive. It is clear that ranaviruses can persist for long periods in frozen carcasses (e.g., Langdon 1989). In environments that freeze soon after die-offs, frozen carcasses might be an important source of ranavirus infection in the following year (Bollinger et al. 1999). Alternatively, individuals of certain species or life history stages that are carriers (i.e., remain infected and infectious for long periods without clearing or succumbing to the infection) may act as reservoirs for more susceptible species or stages (Haydon et al. 2002). In general, only a small fraction of individuals survive for weeks or months with inapparent infections (Langdon 1989; Cullen and Owens 2002; Brunner et al. 2004; Robert et al. 2007; Haislip et al. 2011; Hoverman et al. 2011; Brenes 2013; Brenes et al. 2014b). For example, of the 43 ectothermic vertebrate species challenged with FV3-like ranaviruses by Hoverman et al. (2011), Haislip et al. (2011), Brenes (2013), and Brenes et al. (2014b), there was about an $85 \%$ correlation between infection and mortality after 28 days. Still, it may take only a few subclinically infected individuals to transmit ranavirus to more susceptible individuals or species, thereby initiating outbreaks (Brunner et al. 2004). Additionally, Robert et al. (2007) demonstrated that X. laevis, which is generally resistant to FV3 infections, can be asymptomatic carriers. In a subsequent study, Morales et al. (2010) showed that peritoneal macrophages sometimes harbor quiescent FV3 infections for at least 3 weeks. Asymptomatic infections can be reactivated 
in animals that are immunocompromised by $\gamma$-irradiation (Robert et al. 2007). Whether these inapparently infected Xenopus or individuals of other species survive and retain infections over longer periods, and how they can transmit the infection to other individuals remain open questions (but see Sect. 3.2).

\section{Selection and Coevolution of Ranaviruses and Their Hosts}

Ranaviruses can be a strong selective force on their host populations, frequently causing epidemics that result in extreme population fluctuations and even localized extinctions. As an example, past selection by ranavirus infections appears to favor certain MHC Class I alleles (associated with viral recognition and antigen presentation) among European common frog populations. Particular MHC Class I alleles were found in higher frequencies among populations with a history of ranaviral disease relative to populations with no history of infection (Teacher et al. 2009). In addition, decreases in heterozygosity and relatedness were observed, suggesting epidemics led to behavioral changes in mating patterns (Teacher et al. 2009).

There is ample evidence of variation among amphibian populations in their susceptibility to ranaviruses, presumably because of underlying genetic differences. Laboratory experiments commonly reveal dramatic differences in mortality or infection rates between populations (Pearman et al. 2004; Brunner et al. 2005; Pearman and Garner 2005; Schock et al. 2008; Brunner and Collins 2009; Echaubard et al. 2014). As an example, Pearman et al. (2004) found that two populations of Italian agile frog (Rana latastei) with low genetic diversity experienced $100 \%$ mortality in just 5 days following exposure to FV3, while four other populations with higher genetic diversity experienced 40-70\% mortality. Similarly, inbred lines of the African clawed frog tadpoles had dramatically lower survival times than outbred lines (Gantress et al. 2003).

Given the large, and presumably heritable, variation in susceptibility and the strong selective pressure placed on host populations by ranaviruses, we would generally expect ranaviruses and their hosts to coevolve. This coevolutionary potential is exemplified by the tiger salamander-ATV system because tiger salamanders are commonly found in the absence of other amphibians and epidemics are common (Brunner et al. 2004). Three lines of evidence suggest coevolution in this system. First, there is a negative correlation between disease frequency and cannibal frequency among salamander populations throughout Arizona (Pfennig et al. 1991). Although cannibals enjoy a performance advantage by preying on conspecifics (Reilly et al. 1992), cannibalism comes at the cost of increased risk of acquiring ATV (and other pathogens) from conspecifics, such that reduced cannibalism might prevent disease spread (Pfennig et al. 1991; Bolker et al. 2008). Common garden experiments suggest these patterns are genetically based and thus likely result from past selection (Parris et al. 2005). Animals were not plastic in development of the cannibalistic phenotype between treatments with and without ATV, and observed differences in the frequency of cannibals in the field were replicated in the lab (Parris et al. 2005). 
Second, the tight coupling of viral persistence and the life cycle of the host suggests a coevolutionary history. Larvae, branchiate adults, and metamorphosed adults are all susceptible to ATV, but larvae are significantly more likely to recover than metamorphs (Brunner et al. 2004). Ranavirus epidemics occur in ponds in the larval stage, but many metamorphs leave ponds with sublethal infections, overwinter, and return in later years to breed (Brunner et al. 2004). Salamanders themselves are thus a critical reservoir for ATV, serving as a key source of virus transmission among or within populations across years.

Third, molecular genetic analyses of phylogenetic concordance suggest coevolution between salamander populations and local ATV strains (Storfer et al. 2007). Excluding the three host switches attributed to the movement of infected salamanders as fishing bait (Jancovich et al. 2005), there is complete concordance between phylogenetic trees for both salamanders and virus (Storfer et al. 2007). In addition, nodal depths, or the timing of putative speciation or divergence events, were strongly correlated in ATV strains and their associated tiger salamander populations (Storfer et al. 2007). Moreover, there appears to be local selection for molecular evolution of different ATV strains in different tiger salamander populations. ATV genes associated with host immune evasion (Jancovich and Jacobs 2011) have evolved unique amino acid differences among spatially distinct tiger salamander populations independently of their phylogenetic relationships (Ridenhour and Storfer 2008). Taken together, these findings provide strong support for a coevolutionary history of ATV and its tiger salamander host.

\section{The Evolution of Virulence in Ranaviruses}

Although ranaviruses are often recognized for their high virulence, there is wide variation in virulence among viral strains and host species. For example, Brunner and Collins (2009) challenged tiger salamander larvae with nine strains of ATV and found that virulence (measured as the time to death) varied substantially among isolates and was apparently heritable. This and similar results from many other studies that consider virulence raise the question: why are some viruses or strains more virulent than others?

One widespread and important hypothesis for variation in virulence posits a trade-off between transmission and virulence, the latter of which is generally seen as an unavoidable by-product of replicating in and being transmitted from the host (Lenski and May 1994; Alizon et al. 2009). Highly virulent pathogens may have fewer opportunities for transmission than less virulent strains because they rapidly kill their hosts, leading to the widespread assumption that parasites evolve to intermediate virulence levels. However the optimal level of virulence, and even the existence of a trade-off, depends heavily on the ecology of the host (e.g., density, background mortality), pathogen (e.g., competition between pathogens within a host, host immune responses), and their interaction (e.g., transmission mode, cause of pathogenesis; Day 2001; Day 2002; Day and Proulx 2004; Ebert 1999). 
Conditions that favor rapid transmission (e.g., dense host populations, an influx of naïve hosts), reduce the infectious period (e.g., high background mortality rates, rapid clearance by the immune system), or lead to competition among strains within hosts (i.e., multiple infections) generally favor more virulent pathogens (May and Nowak 1994; Ebert and Mangin 1997; Williams and Day 2001; Cooper et al. 2002; Gandon et al. 2002; Day 2003; Restif and Koella 2003; Alizon and van Baalen 2008). Hosts that tolerate infections (i.e., minimize the fitness consequences) rather than resist or clear infections are expected to circumvent the evolution of increased host virulence (Roy and Kirchner 2000; Restif and Koella 2003). The details of the host-pathogen system, however, often drive the expected evolutionary dynamics (Day 2001, 2002; Sabelis and Metz 2002; Day and Proulx 2004), so we must be careful in applying virulence theory to ranavirus-host systems.

One pattern that is becoming clear, however, is that ranaviruses isolated from captive settings (e.g., aquaculture and ranaculture facilities, bait shops) are more virulent relative to wild strains. For instance, an ATV strain isolated from a fishing bait store was significantly more virulent (i.e., caused greater mortality) to tiger salamander larvae than native strains (Storfer et al. 2007). Similarly, an FV3 strain isolated from a bullfrog farm in Idaho (RCV-Z; Majji et al. 2006) grew significantly faster in vivo and caused significantly higher mortality in bullfrog and spotted frog (Lithobates luteiventris) tadpoles than a strain isolated from a wild bullfrog population in Washington (AS, KC, Washington State University, unpublished data). Hoverman et al. (2011) also found that an FV3-like ranavirus from a captive bullfrog facility was more virulent, causing an average of $51 \%$ more mortality in laboratory experiments across eight species of larval anurans, compared to the type isolate of FV3. An FV3-like ranavirus isolated from a pallid sturgeon hatchery has proven to be among the most virulent strains identified to date (Waltzek et al. 2014).

There are several hypotheses that might explain the evolution of increased virulence of ranaviruses in captive settings. First, the cost of virulence-host death before transmission has occurred-may be reduced in captive settings because of high rates of background mortality or because conditions promote rapid transmission. High stocking densities are likely to increase contact rates and the buildup of shed virions, both of which will increase transmission rates. Also, the death of the host is not the end of the infectious period for ranaviruses. Depending on the facility, infectious carcasses may not be removed before susceptible individuals scavenge them and become infected, whereas in nature other scavengers and organisms that facilitate decomposition are likely to be more abundant, and thus these carcasses disappear more quickly. Second, selection during the initial phases of a growing epidemic, when susceptible hosts are not limiting, should favor rapid transmission and virulence (Day and Proulx 2004; Bolker et al. 2010). If new, susceptible animals are continually introduced into a population undergoing an epidemic, as appears to be the case in some bait shops selling tiger salamanders (Picco and Collins 2008), this could favor more proliferative, virulent viral strains over those that would be favored when hosts become limiting. Lastly, competition between pathogens within a host can favor increased virulence, even at the cost of reduced transmission (e.g., de Roode et al. 2005). Captive settings, which often receive animals from many 
sources (e.g., Woodland et al. 2002b), may harbor several co-circulating ranavirus strains, with the effect of selecting the most virulent strains (Antia et al. 1994; Bull 1994). While all of these hypotheses remain to be tested, collectively their logic suggests a need to change the conditions and practices in captive facilities that may promote ranavirus transmission, mixing, and persistence.

These results also raise concern that introduction of infected bait tiger salamanders or American bullfrogs may introduce novel, highly virulent viral strains into areas with naïve hosts or into areas where hosts have been previously exposed but are adapted to other ranavirus strains. Bullfrogs in particular comprise a major portion of amphibians involved in international trade. Schloegel et al. (2009) reported that over 28 million amphibians were imported into the USA during 2000-2005, with an $8.5 \%$ prevalence of ranavirus infection. Farmed and wild bullfrogs and other amphibians are traded globally in enormous quantities (Altherr et al. 2011), making international trade an important route for the translocation and introduction of ranaviruses (Fig. 2, Schloegel et al. 2010). A key question is thus whether introduced, virulent ranavirus strains persist or outcompete resident strains of ranavirus in the wild.

\section{The Risk of Extinction from Ranaviruses}

De Castro and Bolker (2005) reviewed three theoretical mechanisms by which pathogens could cause the extinction of their host. First, small, isolated populations may be at risk of stochastic extinction from disease. Highly transmissible, virulent pathogens, such as ranaviruses, can also reduce initially dense populations to levels where demographic fluctuations or related genetic effects (e.g., inbreeding) can lead to stochastic extinction. Second, pathogens transmitted in a density-independent fashion are capable of continued transmission as host densities decline, even to the point of host extinction. One common example of density-independent transmission is sexually transmitted infections, but any form of aggregation (e.g., localized feeding or breeding sites) can maintain high rates of transmission, regardless of host density. Even brief periods of density-independent transmission (e.g., during breeding) can lead to pathogen-driven extinction (Ryder et al. 2007). Third, pathogens that have biotic (other species) or abiotic (environmental) reservoirs will also continue to infect hosts irrespective of host densities, and so have the potential to cause host extinction.

Ranaviruses appear to meet the conditions required to cause host extinction by any or all of these mechanisms (Miller et al. 2011). Given the broad host range and frequent movement of ranaviruses in regional and international trade, it is easy to imagine how a highly virulent and transmissible ranavirus might be introduced into small or naïve populations. Second, while a laboratory experiment with ATV in tiger salamander larvae found that the rate of transmission increased with the density of infected larvae, it quickly saturated and led to substantial rates of infection even at the lowest density (Greer et al. 2008). Moreover, there are many examples of ectothermic vertebrates aggregating as they feed, shelter, and mate, which could 
lead to at least short-term density-independent transmission. Lastly, as noted above, ranaviruses may persist in the environment long enough to be transmitted to naïve hosts. Perhaps more importantly, fish, amphibians and reptiles often overlap with other, less susceptible or more abundant species that act as biotic reservoirs for the species of interest. Collectively, there is good reason to think that ranaviruses can lead to host extinction (Miller et al. 2011).

In spite of this potential for ranaviruses to cause host extinctions, it is difficult to find specific examples of ranavirus leading to regional or global extinctions or, until recently, declines. Few long-term datasets exist that have followed wild populations of ectothermic vertebrates with reoccurring die-offs from ranavirus, and at least for amphibians, long datasets are often required to be certain of declines (Alford and Richards 1999). To some degree this may be explained by the fact that ranaviruses often affect the larval or juvenile stages (see Sects. 2.1 and 3.3) and for many taxa these stages can be less important demographically than adults (Biek et al. 2002). We would thus expect populations or species where the adults were most affected by ranaviruses to display the greatest declines (but see Earl and Gray 2014). Indeed, Teacher et al. (2010) reported an $81 \%$ median reduction in population abundance of common frog (Rana temporaria) adults at ponds in the UK with known reoccurring die-offs from ranaviral disease. Again, ranaviruses in the UK appear to primarily affect adults (Cunningham et al. 1993; Teacher et al. 2010; Duffus et al. 2013). Similarly, the significant ranavirus mortality observed in adult turtles presumably puts these populations at increased risk of extinction as well (Belzer and Seibert 2011; Farnsworth and Seigel 2013).

Repeated ranavirus epidemics in larval amphibians may also lead to declines and local extinctions. Petranka et al. (2003, 2007), for instance, reported minimal recruitment of wood frogs at several newly constructed wetlands over an 8-year period due to annual die-offs from ranaviral disease. Recently, Earl and Gray (2014) used a matrix population-projection model to demonstrate that local extirpation of a closed wood frog population was likely if larvae or metamorphs were exposed to ranavirus once every 5 years. For populations that were exposed every year, time to extinction could be as rapid as 5 years (Earl and Gray 2014). Moreover, a sensitivity analysis showed that survival of the pre-metamorphic stages was more important than post-metamorphic stages for the wood frog, providing initial evidence that significant mortality of larvae due to ranavirus could lead to population extinction (Earl and Gray 2014). Susceptible species in fragmented landscapes with limited dispersal may be at greater risk of extinction than has been previously recognized (Collins and Crump 2009).

The most compelling example of recurring ranavirus epidemics leading to amphibian declines comes from the Picos de Europa National park in Spain (Price et al. 2014). These communities were monitored for six years, during which ranaviruses were apparently introduced, leading to significant declines over the following years. What makes these virus-host community interactions different from others that have not suffered declines remains unknown. Clearly, there is a need for more studies of the population-level effects of ranavirus outbreaks, particularly long-term studies of sites with reoccurring ranavirus die-offs (Gray et al. 2015). 
Additionally, it will be important to incorporate host and virus dispersal (e.g., metapopulation dynamics) into mathematical models and studies to understand the risk that ranaviruses pose to their ectothermic vertebrate hosts.

Acknowledgments We thank the members of the Brunner lab for comments on early drafts, Jake Kerby and David Lesbarrères for their careful reviews and helpful suggestions, and the editors, without whose enormous efforts this chapter and book would not exist. AS would like to acknowledge funding from NSF grant DEB 1316549.

Open Access publication was made possible through grants provided by the University of Tennessee (Institute of Agriculture, Office of Research and Engagement, and Department of Forestry, Wildlife and Fisheries), Washington State University Libraries, Gordon State College (Office of Academic Affairs), the Association of Reptilian and Amphibian Veterinarians, and the Amphibian and Reptile Conservancy.

Open Access This chapter is distributed under the terms of the Creative Commons Attribution Noncommercial License, which permits any noncommercial use, distribution, and reproduction in any medium, provided the original author(s) and source are credited.

\section{References}

Ahne W, Bremont M, Hedrick RP, Hyatt AD, Whittington RJ (1997) Special topic review: iridoviruses associated with epizootic haematopoietic necrosis (EHN) in aquaculture. World $\mathbf{J}$ Microbiol Biotechnol 13:367-373

Alford RA, Richards SJ (1999) Global amphibian declines: a problem in applied ecology. Annu Rev Ecol Syst 30:133-165

Alizon S, van Baalen M (2008) Multiple infections, immune dynamics, and the evolution of virulence. Am Nat 172:E150-E168

Alizon S, Hurford A, Mideo N, Van Baalen M (2009) Virulence evolution and the trade-off hypothesis: history, current state of affairs and the future. J Evol Biol 22:245-259

Allender MC, Fry MM, Irizarry AR, Craig L, Johnson AJ, Jones M (2006) Intracytoplasmic inclusions in circulating leukocytes from an eastern box turtle (Terrapene carolina carolina) with iridoviral infection. J Wildl Dis 42:677-684

Allender MC, Mitchell MA, McRuer D, Christian S, Byrd J (2013a) Prevalence, clinical signs, and natural history characteristics of frog virus 3-like infections in eastern box turtles (Terrapene carolina carolina). Herpetol Conserv Biol 8:308-320

Allender MC, Mitchell MA, Torres T, Sekowska J, Driskell EA (2013b) Pathogenicity of frog virus 3-like virus in red-eared slider turtles (Trachemys scripta elegans) at two environmental temperatures. J Comp Pathol 149:356-367

Altherr S, Goyenechea A, Schubert DJ (2011) Canapés to extinction: the international trade in frogs' legs and its ecological impact. A report by Pro Wildlife, Defenders of Wildlife and Animal Welfare Institute, Washington, DC

Altig R, Whiles MR, Taylor CL (2007) What do tadpoles really eat? Assessing the trophic status of an understudied and imperiled group of consumers in freshwater habitats. Freshw Biol 52:386-395

Altizer S, Ostfeld RS, Johnson PT, Kutz S, Harvell CD (2013) Climate change and infectious diseases: from evidence to a predictive framework. Science 341:514-519

Antia R, Levin BR, May RM (1994) Within-host population dynamics and the evolution and maintenance of microparasite virulence. Am Nat 144:457-472

Ariel E (1997) Pathology and serological aspects of Bohle iridovirus infections in six selected water-associated reptiles in North Queensland. Dissertation, James Cook University, North Queensland 
Ariel E (2011) Viruses in reptiles. Vet Res 42:12

Ariel E, Jensen BB (2009) Challenge studies of European stocks of redfin perch, Perca fluviatilis L., and rainbow trout, Oncorhynchus mykiss (Walbaum), with epizootic haematopoietic necrosis virus. J Fish Dis 32:1017-1025

Ariel E, Owens L (1997) Epizootic mortalities in tilapia Oreochromis mossambicus. Dis Aquat Organ 29:1-6

Ariel E, Kielgast J, Svart HE, Larsen K, Tapiovaara H, Bang JB, Holopainen R (2009a) Ranavirus in wild edible frogs Pelophylax kl. esculentus in Denmark. Dis Aquat Organ 85:7-14

Ariel E, Nicolajsen N, Christophersen MB, Holopainen R, Tapiovaara H, Jensen BB (2009b) Propagation and isolation of ranaviruses in cell culture. Aquaculture 294:159-164

Ariel E, Holopainen R, Olesen NJ, Tapiovaara H (2010) Comparative study of ranavirus isolates from cod (Gadus morhua) and turbot (Psetta maxima) with reference to other ranaviruses. Arch Virol 155:1261-1271

Bang Jensen B, Ersboll AK, Ariel E (2009) Susceptibility of pike Esox lucius to a panel of Ranavirus isolates. Dis Aquat Organ 83:169-179

Bang Jensen B, Reschova S, Cinkova K, Ariel E, Vesely T (2011a) Common carp (Cyprinus carpio) and goldfish (Carassius auratus) were not susceptible to challenge with ranavirus under certain challenge conditions. Bull Eur Assoc Fish Pathol 31:112-118

Bang Jensen B, Holopainen R, Tapiovaara H, Ariel E (2011b) Susceptibility of pike-perch Sander lucioperca to a panel of ranavirus isolates. Aquaculture 313:24-30

Bayley AE, Hill BJ, Feist SW (2013) Susceptibility of the European common frog Rana temporaria to a panel of ranavirus isolates from fish and amphibian hosts. Dis Aquat Organ 103:171-183

Beck BH, Bakal RS, Brunner CJ, Grizzle JM (2006) Virus distribution and signs of disease after immersion exposure to largemouth bass virus. J Aquat Anim Health 18:176-183

Becker JA, Tweedie A, Gilligan D, Asmus M, Whittington RJ (2013) Experimental infection of Australian freshwater fish with epizootic haematopoietic necrosis virus (EHNV). J Aquat Anim Health 25:66-76

Belzer W, Seibert S (2011) A natural history of Ranavirus in an eastern box turtle population. Turtle Tortoise Newsl 15:18-25

Biek R, Funk WC, Maxell BA, Mills LS (2002) What is missing in amphibian decline research: insights from ecological sensitivity analysis. Conserv Biol 16:728-734

Blaustein AR, Gervasi SS, Johnson PT, Hoverman JT, Belden LK, Bradley PW, Xie GY (2012) Ecophysiology meets conservation: understanding the role of disease in amphibian population declines. Philos Trans R Soc Lond B Biol Sci 367:1688-1707

Bolker BM, de Castro F, Storfer A, Mech S, Harvey E, Collins JP (2008) Disease as a selective force precluding widespread cannibalism: a case study of an iridovirus of tiger salamanders, Ambystoma tigrinum. Evol Ecol Res 10:105-128

Bolker BM, Nanda A, Shah D (2010) Transient virulence of emerging pathogens. J R Soc Interface 7:811-822

Bollinger TK, Mao J, Schock D, Brigham RM, Chinchar VG (1999) Pathology, isolation, and preliminary molecular characterization of a novel iridovirus from tiger salamanders in Saskatchewan. J Wildl Dis 35:413-429

Brenes R (2013) Mechanisms contributing to the emergence of ranavirus in ectothermic vertebrate communities. Dissertation, University of Tennessee, Knoxville

Brenes R, Gray MJ, Waltzek TB, Wilkes RP, Miller DL (2014a) Transmission of ranavirus between ectothermic vertebrate hosts. PLoS One 9:e92476

Brenes R, Miller DL, Waltzek TB, Wilkes RP, Tucker JL, Chaney JC, Hardman RH, Brand MD, Huether RR, Gray MJ (2014b) Susceptibility of fish and turtles to three ranaviruses isolated from different ectothermic vertebrate classes. J Aquat Anim Health 26:118-126

Brunner JL, Collins JP (2009) Testing assumptions of the trade-off theory of the evolution of parasite virulence. Evol Ecol Res 11:1169-1188

Brunner JL, Schock DM, Collins JP, Davidson EW (2004) The role of an intraspecific reservoir in the persistence of a lethal ranavirus. Ecology 85:560-566 
Brunner JL, Richards K, Collins JP (2005) Dose and host characteristics influence virulence of ranavirus infections. Oecologia 144:399-406

Brunner JL, Schock DM, Collins JP (2007) Transmission dynamics of the amphibian ranavirus Ambystoma tigrinum virus. Dis Aquat Organ 77:87-95

Brunner JL, Barnett KE, Gosier CJ, McNulty SA, Rubbo MJ, Kolozsvary MB (2011) Ranavirus infection in die-offs of vernal pool amphibians in New York, USA. Herpetol Rev 42:76-79

Bull JJ (1994) Perspective: virulence. Evolution 48:1423-1437

Carey C, Cohen N, Rollins-Smith L (1999) Amphibian declines: an immunological perspective. Dev Comp Immunol 23:459-472

Chinchar VG (2002) Ranaviruses (family Iridoviridae): emerging cold-blooded killers. Arch Virol $147: 447-470$

Chinchar VG, Waltzek TB (2014) Ranaviruses: not just for frogs. PLoS Pathog 10:e1003850

Chinchar VG, Wang J, Murti G, Carey C, Rollins-Smith L (2001) Inactivation of frog virus 3 and channel catfish virus by esculentin-2P and ranatuerin-2P, two antimicrobial peptides isolated from frog skin. Virology 288:351-357

Chinchar VG, Bryan L, Silphadaung U, Noga E, Wade D, Rollins-Smith L (2004) Inactivation of viruses infecting ectothermic animals by amphibian and piscine antimicrobial peptides. Virology 323:268-275

Chinchar VG, Hyatt AD, Miyazaki T, Williams T (2009) Family Iridoviridae: poor viral relations no longer. In: Van Etten JL (ed) Current topics in microbiology and immunology, vol 328, Lesser known large dsDNA viruses. Springer, Berlin

Chua FHC, Ng ML, Ng KL, Loo JJ, Wee JY (1994) Investigation of outbreaks of a novel disease, 'Sleepy Grouper Disease', affecting the brown-spotted grouper, Epinephelus tauvina Forska. J Fish Dis 17:417-427

Collins JP, Crump ML (2009) Extinction in our times: global amphibian decline. Oxford University Press, Oxford

Cooper VS, Reiskind MH, Miller JA, Shelton KA, Walther BA, Elkinton JS, Ewald PW (2002) Timing of transmission and the evolution of virulence of an insect virus. Proc R Soc Lond B Biol Sci 269:1161-1165

Crump ML (1983) Opportunistic cannibalism by amphibian larvae in temporary aquatic environments. Am Nat 121:281-289

Cullen BR, Owens L (2002) Experimental challenge and clinical cases of Bohle iridovirus (BIV) in native Australian anurans. Dis Aquat Organ 49:83-92

Cullen CR, Owens L, Whittington RJ (1995) Experimental infection of Australian anurans (Limnodynastes terraereginae and Litoria latopalmata) with Bohle iridovirus. Dis Aquat Organ 23:83-92

Cunningham AA, Langton TES, Bennet PM, Drury SES, Gough RE, Kirkwood JK (1993) Unusual mortality associated with poxvirus-like particles in frogs (Rana temporaria). Vet Rec 133:141-142

Cunningham AA, Hyatt AD, Russell P, Bennett PM (2007a) Emerging epidemic diseases of frogs in Britain are dependent on the source of ranavirus agent and the route of exposure. Epidemiol Infect 135:1200-1212

Cunningham AA, Hyatt AD, Russell P, Bennett PM (2007b) Experimental transmission of a ranavirus disease of common toads (Bufo bufo) to common frogs (Rana temporaria). Epidemiol Infect 135:1213-1216

Daszak P, Cunningham AA, Hyatt AD (2001) Anthropogenic environmental change and the emergence of infectious diseases in wildlife. Acta Trop 78:103-116

Davidson C, Shaffer HB, Jennings MR (2002) Spatial tests of the pesticide drift, habitat destruction, UV-B, and climate-change hypotheses for California amphibian declines. Conserv Biol $16: 1588-1601$

Day $\mathrm{T}$ (2001) Parasite transmission modes and the evolution of virulence. Evolution $55: 2389-2400$

Day T (2002) Virulence evolution via host exploitation and toxin production in spore-producing pathogens. Ecol Lett 5:471-476 
Day T (2003) Virulence evolution and the timing of disease life-history events. Trends Ecol Evol 18:113-118

Day T, Proulx SR (2004) A general theory for the evolutionary dynamics of virulence. Am Nat 163:E40-E63

de Castro F, Bolker B (2005) Mechanisms of disease-induced extinction. Ecol Lett 8:117-126

de Roode JC, Pansini R, Cheesman SJ, Helinski MEH, Huijben S, Wargo AR, Bell AS, Chan BHK, Walliker D, Read AF (2005) Virulence and competitive ability in genetically diverse malaria infections. Proc Natl Acad Sci U S A 102:7624-7628

DeBenedictis PA (1974) Interspecific competition between tadpoles of Rana pipiens and Rana sylvatica: an experimental field study. Ecol Monogr 44:129-151

Deng GC, Li SJ, Xie J, Bai JJ, Chen KC, Ma DM, Jiang XY, Lao HH, Yu LY (2011) Characterization of a ranavirus isolated from cultured largemouth bass (Micropterus salmoides) in China. Aquaculture 312:198-204

Dhabhar FS (2009) Enhancing versus suppressive effects of stress on immune function: implications for immunoprotection and immunopathology. Neuroimmunomodulation 16:300-317

Duffus ALJ, Pauli BD, Wozney K, Brunetti CR, Berrill M (2008) Frog virus 3-like infections in aquatic amphibian communities. J Wildl Dis 44:109-120

Duffus ALJ, Nichols RA, Garner TWJ (2013) Investigations into the life history stages of the common frog (Rana temporaria) affected by an amphibian ranavirus in the United Kingdom. Herpetol Rev 44:260-263

Duffus ALJ, Marschang RE, Waltzek TB, Stöhr A, Allender MC, Gotesman M, Whittington R, Hick P, Hines M (2015) Distribution and host range of ranaviruses. In: Gray MJ, Chinchar VG (eds) Ranaviruses: lethal pathogens of ectothermic vertebrates. Springer, Secaucus

Earl JE, Gray MJ (2014) Introduction of ranavirus to isolated wood frog populations could cause local extinction. Ecohealth. doi:10.1007/s10393-014-0950-y

Eaton JG, Scheller RM (1996) Effects of climate warming on fish thermal habitat in streams of the United States. Limnol Oceanogr 41:1109-1115

Ebert D (1999) The evolution and expression of parasite virulence. In: Stearns SC (ed) Evolution in health and disease. Oxford University Press, New York

Ebert D, Mangin KL (1997) The influence of host demography on the evolution of virulence of a microsporidian gut parasite. Evolution 51:1828-1837

Echaubard P, Little K, Pauli B, Lesbarrères D (2010) Context-dependent effects of ranaviral infection on Northern leopard frog life history traits. PLoS One 5:e13723

Echaubard P, Leduc J, Pauli B, Chinchar VG, Robert J, Lesbarrères D (2014) Environmental dependency of amphibian-ranavirus genotypic interactions: evolutionary perspectives on infectious diseases. Evol Appl 7:723-733

Farnsworth S, Seigel R (2013) Responses, movements, and survival of relocated box turtles during construction of the intercounty connector highway in Maryland. Transp Res Rec 2362:1-8

Forson D, Storfer A (2006a) Effects of atrazine and iridovirus infection on survival and life history characteristics in long-toed salamanders, Ambystoma macrodactylum. Environ Toxicol Chem 25:168-173

Forson DD, Storfer A (2006b) Atrazine increases ranavirus susceptibility in the tiger salamander, Ambystoma tigrinum. Ecol Appl 16:2325-2332

Fox S, Greer AL, Torres-Cervantes R, Collins JP (2006) First case of ranavirus-associated morbidity and mortality in natural populations of the South American frog Atelognathus patagonicus. Dis Aquat Organ 72:87-92

Fraker ME, Hu F, Cuddapah V, McCollum SA, Relyea RA, Hempel J, Denver RJ (2009) Characterization of an alarm pheromone secreted by amphibian tadpoles that induces behavioral inhibition and suppression of the neuroendocrine stress axis. Horm Behav 55:520-529

Gahl MK, Calhoun AJK (2008) Landscape setting and risk of ranavirus mortality events. Biol Conserv 141:2679-2689

Gahl MK, Calhoun AJK (2010) The role of multiple stressors in ranavirus-caused amphibian mortalities in Acadia national park wetlands. Can J Zool 88:108-121 
Gandon S, van Baalen M, Jansen VAA (2002) The evolution of parasite virulence, superinfection, and host resistance. Am Nat 159:658-669

Gantress J, Maniero GD, Cohen N, Robert J (2003) Development and characterization of a model system to study amphibian immune responses to iridoviruses. Virology 311:254-262

Gobbo F, Cappellozza E, Pastore MR, Bovo G (2010) Susceptibility of black bullhead Ameiurus melas to a panel of ranavirus isolates. Dis Aquat Organ 90:167-174

Goldberg TL (2002) Largemouth bass virus: an emerging problem for warmwater fisheries? In: Philipp DP, Ridgway MS (eds) American Fisheries Society symposium 31, Bethesda

Goodman RM, Miller DL, Ararso YT (2013) Prevalence of ranavirus in Virginia turtles as detected by tail-clip sampling versus oral-cloacal swabbing. Northeast Nat 20:325-332

Gosner KL (1960) A simplified table for staging anuran embryos and larvae with notes on identification. Herpetologica 16:183-190

Granoff A, Came PE, Breeze DC (1966) Viruses and renal carcinoma of Rana pipiens I. The isolation and properties of virus from normal and tumor tissue. Virology 29:133-148

Grant EC, Philipp DP, Inendino KR, Goldberg TL (2003) Effects of temperature on the susceptibility of largemouth bass to largemouth bass virus. J Aquat Anim Health 15:215-220

Grant EC, Inendino KR, Love WJ, Philipp DP, Goldberg TL (2005) Effects of practices related to catch-and-release angling on mortality and viral transmission in juvenile largemouth bass infected with largemouth bass virus. J Aquat Anim Health 17:315-322

Gray MJ, Miller DL, Schmutzer AC, Baldwin CA (2007) Frog virus 3 prevalence in tadpole populations inhabiting cattle-access and non-access wetlands in Tennessee, USA. Dis Aquat Organ 77:97-103

Gray MJ, Miller DL, Hoverman JT (2009a) Ecology and pathology of amphibian ranaviruses. Dis Aquat Organ 87:243-266

Gray MJ, Miller DL, Hoverman JT (2009b) First report of ranavirus infecting lungless salamanders. Herpetol Rev 40:316-319

Gray MJ, Brunner JL, Earl JE, Ariel E (2015) Design and analysis of ranavirus studies: surveillance and assessing risk. In: Gray MJ, Chinchar VG (eds) Ranaviruses: lethal pathogens of ectothermic vertebrates. Springer, Secaucus

Green DE, Converse KA (2005) Diseases of frogs and toads. In: Majumdar SK, Huffman JE, Brenner FJ, Panah AI (eds) Wildlife diseases: landscape epidemiology, spatial distribution and utilization of remote sensing technology. Easton, Pennsylvania

Green DE, Converse KA, Schrader AK (2002) Epizootiology of sixty-four amphibian morbidity and mortality events in the USA, 1996-2001. Ann N Y Acad Sci 969:323-339

Greer AL, Collins JP (2008) Habitat fragmentation as a result of biotic and abiotic factors controls pathogen transmission throughout a host population. J Anim Ecol 77:364-369

Greer AL, Berrill M, Wilson PJ (2005) Five amphibian mortality events associated with ranavirus infection in south central Ontario, Canada. Dis Aquat Organ 67:9-14

Greer AL, Briggs CJ, Collins JP (2008) Testing a key assumption of host-pathogen theory: density and disease transmission. Oikos 117:1667-1673

Greer AL, Brunner JL, Collins JP (2009) Spatial and temporal patterns of Ambystoma tigrinum virus (ATV) prevalence in tiger salamanders (Ambystoma tigrinum nebulosum). Dis Aquat Organ 85:1-6

Grizzle JM, Brunner CJ (2003) Review of largemouth bass virus. Fisheries 28:10-14

Grizzle JM, Altinok I, Fraser WA, Francis-Floyd R (2002) First isolation of largemouth bass virus. Dis Aquat Organ 50:233-235

Groocock GH, Grimmett SG, Getchell RG, Wooster GA, Bowser PR (2008) A survey to determine the presence and distribution of largemouth bass virus in wild freshwater bass in New York State. J Aquat Anim Health 20:158-164

Gruia-Gray J, Desser SS (1992) Cytopathological observations and epizootiology of frog erythrocytic virus in bullfrogs (Rana catasbeiana). J Wildl Dis 28:34-41

Gruia-Gray J, Petric M, Desser S (1989) Ultrastructural, biochemical, and biophysical properties of an erythrocytic virus of frogs from Ontario, Canada. J Wildl Dis 25:497-506 
Haddad JJ, Saadé NE, Safieh-Garabedian B (2002) Cytokines and neuro-immune-endocrine interactions: a role for the hypothalamic-pituitary-adrenal revolving axis. J Neuroimmunol 133:1-19

Haislip NA, Gray MJ, Hoverman JT, Miller DL (2011) Development and disease: how susceptibility to an emerging pathogen changes through anuran development. PLoS One 6:e22307

Haislip NA, Hoverman JT, Miller DL, Gray MJ (2012) Natural stressors and disease risk: does the threat of predation increase amphibian susceptibility to ranavirus? Can J Zool 90:893-902

Hanson LA, Petrie-Hanson L, Meals KO, Chinchar VG, Rudis M (2001) Persistence of largemouth bass virus infection in a northern Mississippi reservoir after a die-off. J Aquat Anim Health 13:27-34

Harikrishnan R, Balasundaram C, Heo M-S (2010) Molecular studies, disease status and prophylactic measures in grouper aquaculture: economic importance, diseases and immunology. Aquaculture 309:1-14

Harp EM, Petranka JW (2006) Ranavirus in wood frogs (Rana sylvatica): potential sources of transmission within and between ponds. J Wildl Dis 42:307-318

Haydon DT, Cleaveland S, Taylor LH, Laurenson MK (2002) Identifying reservoirs of infection: a conceptual and practical challenge. Emerg Infect Dis 8:1468-1473

Homan RN, Bartling JR, Stenger RJ, Brunner JL (2013) Detection of Ranavirus in Ohio, USA. Herpetol Rev 44:615-618

Hoverman JT, Gray MJ, Miller DL (2010) Anuran susceptibilities to ranaviruses: role of species identity, exposure route, and a novel virus isolate. Dis Aquat Organ 89:97-107

Hoverman JT, Gray MJ, Haislip NA, Miller DL (2011) Phylogeny, life history, and ecology contribute to differences in amphibian susceptibility to ranaviruses. Ecohealth 8:301-319

Hoverman JT, Gray MJ, Miller DL, Haislip NA (2012) Widespread occurrence of ranavirus in pond-breeding amphibian populations. Ecohealth 9:36-48

Huang SM, Tu C, Tseng CH, Huang CC, Chou CC, Kuo HC, Chang SK (2011) Genetic analysis of fish iridoviruses isolated in Taiwan during 2001-2009. National Taiwan University, Graduate Institute of Veterinary Medicine, Taipei

Jancovich JK, Jacobs BL (2011) Innate immune evasion mediated by the Ambystoma tigrinum virus eukaryotic translation initiation factor $2 \alpha$ homologue. J Virol 85:5061-5069

Jancovich JK, Davidson EW, Morado JF, Jacobs BL, Collins JP (1997) Isolation of a lethal virus from the endangered tiger salamander Ambystoma tigrinum stebbinsi. Dis Aquat Organ 31:161-167

Jancovich JK, Davidson EW, Seiler A, Jacobs BL, Collins JP (2001) Transmission of the Ambystoma tigrinum virus to alternative hosts. Dis Aquat Organ 46:159-163

Jancovich J, Davidson EW, Parameswaran N, Mao J, Chinchar VG, Collins JP, Jacobs BL, Storfer A (2005) Evidence for emergence of an amphibian iridoviral disease because of humanenhanced spread. Mol Ecol 14:213-224

Johnson AF, Brunner JL (2014) Persistence of an amphibian ranavirus in aquatic communities. Dis Aquat Organ 111:129-138

Johnson AJ, Pessier AP, Jacobson ER (2007) Experimental transmission and induction of ranaviral disease in western ornate box turtles (Terrapene ornata ornata) and red-eared sliders (Trachemys scripta elegans). Vet Pathol 44:285-297

Johnson AJ, Pessier AP, Wellehan JFX, Childress A, Norton TM, Stedman NL, Bloom DC, Belzer W, Titus VR, Wagner R, Brooks JW, Spratt J, Jacobson ER (2008) Ranavirus infection of freeranging and captive box turtles and tortoises in the United States. J Wildl Dis 44:851-863

Johnson AJ, Wendland L, Norton TM, Belzer B, Jacobson ER (2010) Development and use of an indirect enzyme-linked immunosorbent assay for detection of iridovirus exposure in gopher tortoises (Gopherus polyphemus) and eastern box turtles (Terrapene carolina carolina). Vet Microbiol 142:160-167

Johnson PT, Rohr JR, Hoverman JT, Kellermanns E, Bowerman J, Lunde KB (2012) Living fast and dying of infection: host life history drives interspecific variation in infection and disease risk. Ecol Lett 15:235-242

Keeling MJ, Rohani P (2008) Modeling infectious diseases in humans and animals. Princeton University Press, Princeton 
Kerby JL, Storfer A (2009) Combined effects of atrazine and chlorpyrifos on susceptibility of the tiger salamander to Ambystoma tigrinum virus. Ecohealth 6:91-98

Kerby JL, Hart AJ, Storfer A (2011) Combined effects of virus, pesticide, and predator cue on the larval tiger salamander (Ambystoma tigrinum). Ecohealth 8:46-54

Kik M, Martel A, Sluijs AS, Pasmans F, Wohlsein P, Grone A, Rijks JM (2011) Ranavirusassociated mass mortality in wild amphibians, the Netherlands, 2010: a first report. Vet J 190:284-286

Kimble SJ, Karna AK, Johnson AJ, Hoverman JT, Williams RN (2014) Mosquitoes as a Potential Vector of Ranavirus Transmission in Terrestrial Turtles. Ecohealth http://dx.doi.org/10.1007/ s10393-014-0974-3

Langdon JS (1989) Experimental transmission and pathogenicity of epizootic haematopoietic necrosis virus (EHNV) in redfin perch, Perca fluviatilis L., and 11 other teleosts. J Fish Dis 12:295-310

Langdon JS, Humphrey JD (1987) Epizootic haematopoietic necrosis, a new viral disease in redfin perch, Perca fluviatilis L., in Australia. J Fish Dis 10:289-297

Langdon JS, Humphrey JD, Williams LM, Hyatt AD, Westbury HA (1986) First virus isolation from Australian fish: an iridovirus-like pathogen from redfin perch, Perca fluviatilis L. J Fish Dis 9:263-268

Langdon JS, Humphrey JD, Williams LM (1988) Outbreaks of an EHNV-like iridovirus in cultured rainbow trout, Salmo gairdneri Richardson, in Australia. J Fish Dis 11:93-96

Lenski RE, May RM (1994) The evolution of virulence in parasites and pathogens: reconciliation between two competing hypotheses. J Theor Biol 169:253-265

Maceina MJ, Grizzle JM (2006) The relation of largemouth bass virus to largemouth bass population metrics in five Alabama reservoirs. Trans Am Fish Soc 135:545-555

Majji S, LaPatra S, Long SM, Sample R, Bryan L, Sinning A, Chinchar VG (2006) Rana catesbeiana virus z (RCV-Z): a novel pathogenic ranavirus. Dis Aquat Organ 73:1-11

Mao J, Green DE, Fellers G, Chinchar VG (1999) Molecular characterization of iridoviruses isolated from sympatric amphibians and fish. Virus Res 63:45-52

Marcogliese DJ, Pietrock M (2011) Combined effects of parasites and contaminants on animal health: parasites do matter. Trends Parasitol 27:123-130

Martin LB (2009) Stress and immunity in wild vertebrates: timing is everything. Gen Comp Endocrinol 163:70-76

May R, Nowak M (1994) Coinfection and the evolution of parasite virulence. Proc R Soc Lond B Biol Sci 255:81-89

Miller D, Gray M, Storfer A (2011) Ecopathology of ranaviruses infecting amphibians. Viruses 3:2351-2373

Moody NJG, Owens L (1994) Experimental demonstration of the pathogenicity of a frog virus, Bohle iridovirus, for a fish species, barramundi Lates calcarifer. Dis Aquat Organ 18:95-102

Morales HD, Abramowitz L, Gertz J, Sowa J, Vogel A, Robert J (2010) Innate immune responses and permissiveness to ranavirus infection of peritoneal leukocytes in the frog Xenopus laevis. J Virol 84:4912-4922

Muths E, Gallant AL, Campbell Grant EH, Battaglin WA, Green DE, Staiger JS, Walls SC, Gunzburger MS, Kearney RF (2006) The Amphibian Research and Monitoring Initiative (ARMI): 5-year report. Scientific investigations report 2006-5224. U.S. Geological Survey, Reston

Nagasawa K, Cruz-Lacierda ER (eds) (2004) Diseases of cultured groupers. Southeast Asian Fisheries Development Center, Aquaculture Department, Iloilo

Nazir J, Spengler M, Marschang RE (2012) Environmental persistence of amphibian and reptilian ranaviruses. Dis Aquat Organ 98:177-184

Parris MJ, Storfer A, Collins JP, Davidson EW (2005) Life-history responses to pathogens in tiger salamander (Ambystoma tigrinum) larvae. J Herpetol 39:366-372

Paull SH, Song S, McClure KM, Sackett LC, Kilpatrick AM, Johnson PT (2012) From superspreaders to disease hotspots: linking transmission across hosts and space. Front Ecol Environ $10: 75-82$ 
Pearman PB, Garner TWJ (2005) Susceptibility of Italian agile frog populations to an emerging strain of Ranavirus parallels population genetic diversity. Ecol Lett 8:401-408

Pearman PB, Garner TWJ, Straub M, Greber UF (2004) Response of the Italian agile frog (Rana latastei) to a ranavirus, frog virus 3: a model for viral emergence in naive populations. J Wildl Dis 40:660-669

Petranka JW, Murray SS, Kennedy CA (2003) Responses of amphibians to restoration of a southern Appalachian wetland: perturbations confound post-restoration assessment. Wetlands 23:278-290

Petranka JW, Harp EM, Holbrook CT, Hamel JA (2007) Long-term persistence of amphibian populations in a restored wetland complex. Biol Conserv 138:371-380

Pfennig DW, Loeb MLG, Collins JP (1991) Pathogens as a factor limiting the spread of cannibalism in tiger salamanders. Oecologia 88:161-166

Picco AM, Collins JP (2008) Amphibian commerce as a likely source of pathogen pollution. Conserv Biol 22:1582-1589

Picco AM, Karam AP, Collins JP (2010) Pathogen host switching in commercial trade with management recommendations. Ecohealth 7:252-256

Plumb JA, Zilberg D (1999a) Survival of largemouth bass iridovirus in frozen fish. J Aquat Anim Health 11:94-96

Plumb JA, Zilberg D (1999b) The lethal dose of largemouth bass virus in juvenile largemouth bass and the comparative susceptibility of striped bass. J Aquat Anim Health 11:246-252

Plumb JA, Grizzle JM, Young HE, Noyes AD, Lamprecht S (1996) An iridovirus isolated from wild largemouth bass. J Aquat Anim Health 8:265-270

Polis GA, Myers CA (1985) A survey of intraspecific predation among reptiles and amphibians. J Herpetol 19:99-107

Prasankok P, Chutmongkonkul M, Kanchanakhan S (2005) Characterisation of iridovirus isolated from diseased marbled sleepy goby, Oxyeleotris marmoratus. In: Walker P, Lester R, BondadReantaso MG (eds) Diseases in Asian aquaculture V. Fish Health Section, Asian Fisheries Society, Manila

Price S, Garner T, Nichols R, Balloux F, Ayres C, Mora-Cabello de Alba A, Bosch J (2014) Collapse of amphibian communities due to an introduced Ranavirus. Curr Biol 24:2586-2591

Qin QW, Chang SF, Ngoh-Lim GH, Gibson-Kueh S, Shi C, Lam TJ (2003) Characterization of a novel ranavirus isolated from grouper Epinephelus tauvina. Dis Aquat Organ 53:1-9

Raffel TR, Rohr JR, Kiesecker JM, Hudson PJ (2006) Negative effects of changing temperature on amphibian immunity under field conditions. Funct Ecol 20:819-828

Reddacliff LA, Whittington RJ (1996) Pathology of epizootic haematopoietic necrosis virus (EHNV) infection in rainbow trout (Oncorhynchus mykiss Walbaum) and redfin perch (Perca fluviatilis L). J Comp Pathol 115:103-115

Reeve BC, Crespi EJ, Whipps CM, Brunner JL (2013) Natural stressors and ranavirus susceptibility in larval wood frogs (Rana sylvatica). Ecohealth 10:190-200

Reilly SM, Lauder GV, Collins JP (1992) Performance consequences of a trophic polymorphism: feeding behavior in typical and cannibal phenotypes of Ambystoma tigrinum. Copeia (3):672-679

Restif O, Koella JC (2003) Shared control of epidemiological traits in a coevolutionary model of host-parasite interactions. Am Nat 161:827-836

Ridenhour BJ, Storfer AT (2008) Geographically variable selection in Ambystoma tigrinum virus (Iridoviridae) throughout the western USA. J Evol Biol 21:1151-1159

Robert J, Abramowitz L, Gantress J, Morales HD (2007) Xenopus laevis: a possible vector of ranavirus infection? J Wildl Dis 43:645-652

Robert J, George E, De Jesús Andino F, Chen G (2011) Waterborne infectivity of the Ranavirus frog virus 3 in Xenopus laevis. Virology 417:410-417

Rojas S, Richards K, Jancovich JK, Davidson EW (2005) Influence of temperature on ranavirus infection in larval salamanders, Ambystoma tigrinum. Dis Aquat Organ 63:95-100

Rollins-Smith LA (1998) Metamorphosis and the amphibian immune system. Immunol Rev 166:221-230 
Rollins-Smith LA (2009) The role of amphibian antimicrobial peptides in protection of amphibians from pathogens linked to global amphibian declines. Biochim Biophys Acta 1788:1593-1599

Roy BA, Kirchner JW (2000) Evolutionary dynamics of pathogen resistance and tolerance. Evolution 54:51-63

Ryder JJ, Miller MR, White A, Knell RJ, Boots M (2007) Host-parasite population dynamics under combined frequency- and density-dependent transmission. Oikos 116:2017-2026

Sabelis MW, Metz JAJ (2002) Taking stock: relating theory to experiment. In: Dieckmann U, Metz J, Sabelis M, Sigmund K (eds) Adaptive dynamics of infectious diseases: in pursuit of virulence management. Cambridge University Press, New York

Schloegel LM, Picco AM, Kilpatrick AM, Davies AJ (2009) Magnitude of the U.S. trade in amphibians and presence of Batrachochytrium dendrobatidis and ranavirus infection in imported North American bullfrogs (Rana catesbeiana). Biol Conserv 142:1420-1426

Schloegel LM, Daszak P, Cunningham AA, Speare R, Hill B (2010) Two amphibian diseases, chytridiomycosis and ranaviral disease, are now globally notifiable to the world organization for animal health (OIE): an assessment. Dis Aquat Organ 92:101-108

Schock DM, Bollinger TK, Chinchar VG, Jancovich JK, Collins JP (2008) Experimental evidence that amphibian ranaviruses are multi-host pathogens. Copeia 1:133-143

Sheafor B, Davidson EW, Parr L, Rollins-Smith L (2008) Antimicrobial peptide defenses in the salamander, Ambystoma tigrinum, against emerging amphibian pathogens. J Wildl Dis 44:226-236

Sheridan JF, Dobbs C, Brown D, Zwilling B (1994) Psychoneuroimmunology: stress effects on pathogenesis and immunity during infection. Clin Microbiol Rev 7:200-212

Southard GM, Fries LT, Terre DR (2009) Largemouth bass virus in Texas: distribution and management issues. J Aquat Anim Health 21:36-42

Speare R, Smith JR (1992) An iridovirus-like agent isolated from the ornate burrowing frog Limnodynastes ornatus in northern Australia. Dis Aquat Organ 14:51-57

St-Amour V, Wong WM, Garner TW, Lesbarrères D (2008) Anthropogenic influence on prevalence of 2 amphibian pathogens. Emerg Infect Dis 14:1175-1176

Stark T, Laurijssens C, Weterings M, Spitzen-van der Sluijs A, Martel A, Pasmans F (2014) Death in the clouds: ranavirus associated mortality in assemblage of cloud forest amphibians in Nicaragua. Acta Herpetol 9:125-127

Storfer A, Alfaro ME, Ridenhour BJ, Jancovich JK, Mech SG, Parris MJ, Collins JP (2007) Phylogenetic concordance analysis shows an emerging pathogen is novel and endemic. Ecol Lett 10:1075-1083

Sutton W, Gray M, Hoverman JT, Secrist R, Super P, Hardman R, Tucker J, Miller D (2014) Trends in ranavirus prevalence among plethodontid salamanders in the Great Smoky Mountains National Park. EcoHealth http://dx.doi.org/10.1007/s10393-014-0994-z

Teacher AGF, Garner TWJ, Nichols RA (2009) Population genetic patterns suggest a behavioural change in wild common frogs (Rana temporaria) following disease outbreaks (Ranavirus). Mol Ecol 18:3163-3172

Teacher AGF, Cunningham AA, Garner TWJ (2010) Assessing the long term impact of ranavirus infection in wild common frog populations. Anim Conserv 13:514-522

Terrell KA, Quintero RP, Murray S, Kleopfer JD, Murphy JB, Evans MJ, Nissen BD, Gratwicke B (2013) Cryptic impacts of temperature variability on amphibian immune function. J Exp Biol 216:4204-4211

Titus VR, Green TM (2013) Presence of Ranavirus in green frogs and eastern tiger salamanders on Long Island, New York. Herpetol Rev 44:266-267

Todd-Thompson M (2010) Seasonality, variation in species prevalence, and localized disease for Ranavirus in Cades Cove (Great Smoky Mountains National Park) amphibians. Dissertation, University of Tennesse, Knoxville

Tollrian R, Harvell D (1999) The ecology and evolution of inducible defenses. Princeton University Press, Princeton

Torrence SM, Green DE, Benson CJ, Ip HS, Smith LM, McMurry ST (2010) A new ranavirus isolated from Pseudacris clarkii tadpoles in playa wetlands in the southern high plains, Texas. J Aquat Anim Health 22:65-72 
Une Y, Sakuma A, Matsueda H, Nakai K, Murakami M (2009) Ranavirus outbreak in North American bullfrogs (Rana catesbeiana), Japan, 2008. Emerg Infect Dis 15(7):1146-1147

Waltzek TB, Miller DL, Gray MJ, Drecktrah B, Briggler JT, MacConnell B, Hudson C, Hopper L, Friary J, Yun SC, Malm KV, Weber ES, Hedrick RP (2014) New disease records for hatcheryreared sturgeon. I. Expansion of frog virus 3 host range into Scaphirhynchus albus. Dis Aquat Org 111:219-227

Warne RW, Crespi EJ, Brunner JL (2011) Escape from the pond: stress and developmental responses to ranavirus infection in wood frog tadpoles. Funct Ecol 25:139-146

Wheelwright NT, Gray MJ, Hill RD, Miller DL (2014) Sudden mass die-off of a large population of wood frog (Lithobates sylvaticus) tadpoles in Maine, USA, likely due to ranavirus. Herpetol Rev 45:240-242

Whittington RJ, Reddacliff GL (1995) Influence of environmental temperature on experimental infection of redfin perch (Perca fluviatilis) and rainbow trout (Oncorhynchus mykiss) with epizootic haematopoietic necrosis virus, an Australian iridovirus. Aust Vet J 72:421-424

Whittington RJ, Philbey A, Reddacliff GL, Macgown AR (1994) Epidemiology of epizootic hematopoietic necrosis virus (EHNV) infection in farmed rainbow trout, Oncorhynchus mykiss (Walbaum): findings based on virus isolation, antigen capture elisa and serology. J Fish Dis 17:205-218

Whittington RJ, Reddacliff LA, Marsh I, Kearns C, Zupanovic Z, Callinan RB (1999) Further observations on the epidemiology and spread of epizootic haematopoietic necrosis virus (EHNV) in farmed rainbow trout Oncorhynchus mykiss in southeastern Australia and a recommended sampling strategy for surveillance. Dis Aquat Organ 35:125-130

Whittington RJ, Becker JA, Dennis MM (2010) Iridovirus infections in finfish-critical review with emphasis on ranaviruses. J Fish Dis 33:95-122

Williams PD, Day T (2001) Interactions between sources of mortality and the evolution of parasite virulence. Proc R Soc Lond B Biol Sci 268:2331-2337

Williams T, Barbosa-Solomieu V, Chinchar VG (2005) A decade of advances in iridovirus research. Adv Virus Res 65:173-248

Woodland JE, Brunner CJ, Noyes AD, Grizzle JM (2002a) Experimental oral transmission of largemouth bass virus. J Fish Dis 25:669-672

Woodland JE, Noyes AD, Grizzle JM (2002b) A survey to detect largemouth bass virus among fish from hatcheries in the southeastern USA. Trans Am Fish Soc 131:308-311 